\title{
Production of Hypoallergenic Antibacterial Peptides from Defatted Soybean Meal in Membrane Bioreactor: A Bioprocess Engineering Study with Comprehensive Product Characterization
}

\author{
Arijit Nath ${ }^{1}$, Gábor Szécsi ${ }^{1}$, Barbara Csehi², Zsuzsa Mednyánszky ${ }^{3}$, Gabriella Kiskó ${ }^{4}$, \\ Éva Bányai ${ }^{5}$ Mihály Dernovics ${ }^{5}$ and András Koris ${ }^{1 *}$
}

${ }^{1}$ Department of Food Engineering, Faculty of Food Science, Szent István University, Ménesi st 44, HU-1118 Budapest, Hungary

${ }^{2}$ Department of Refrigeration and Livestock Product Technology, Faculty of Food Science, Szent István University, Ménesi st 43-45, HU-1118 Budapest, Hungary

${ }^{3}$ Department of Food Chemistry and Nutrition, Faculty of Food Science, Szent István University, Budapest, Somlói st 14-16, HU-1118 Budapest, Hungary

${ }^{4}$ Department of Food Microbiology and Biotechnology, Faculty of Food Science, Szent István University, Budapest, Somlói st 14-16, HU-1118 Budapest, Hungary

${ }^{5}$ Department of Applied Chemistry, Faculty of Food Science, Szent István University, Budapest, Villányi st 29-33, HU-1118 Budapest, Hungary

Received: October 28, 2016

Accepted: May 19, 2017

\begin{abstract}
Summary
Hypoallergenic antibacterial low-molecular-mass peptides were produced from defatted soybean meal in a membrane bioreactor. In the first step, soybean meal proteins were digested with trypsin in the bioreactor, operated in batch mode. For the tryptic digestion of soybean meal protein, optimum initial soybean meal concentration of $75 \mathrm{~g} / \mathrm{L}$, temperature of $40^{\circ} \mathrm{C}$ and $\mathrm{pH}=9.0$ were determined. After enzymatic digestion, low-molecular-mass peptides were purified with cross-flow flat sheet membrane (pore size $100 \mu \mathrm{m}$ ) and then with tubular ceramic ultrafiltration membrane (molecular mass cut-off $5 \mathrm{kDa}$ ). Effects of transmembrane pressure and the use of a static turbulence promoter to reduce the concentration polarization near the ultrafiltration membrane surface were examined and their positive effects were proven. For the filtration with ultrafiltration membrane, transmembrane pressure of $3 \cdot 10^{5} \mathrm{~Pa}$ with 3-stage discontinuous diafiltration was found optimal. The molecular mass distribution of purified peptides using ultrafiltration membrane was determined by a liquid chromatography-electrospray ionization quadrupole time-of-flight mass spectrometry setup. More than $96 \%$ of the peptides (calculated as relative frequency) from the ultrafiltration membrane permeate had the molecular mass $M \leq 1.7 \mathrm{kDa}$ and the highest molecular mass was found to be $3.1 \mathrm{kDa}$. The decrease of allergenic property due to the tryptic digestion and membrane filtration was determined by an enzyme-linked immunosorbent assay and it was found to exceed $99.9 \%$. It was also found that the peptides purified in the ultrafiltration membrane promoted the growth of Pediococcus acidilactici HA6111-2 and they possessed antibacterial activity against Bacillus cereus.
\end{abstract}

Key words: soybean meal, enzymatic hydrolysis, peptide separation, low-molecular-mass antibacterial peptides

*Corresponding author: Phone: +361 305 7112; Fax: +361 305 7323; E-mail: koris.andras@etk.szie.hu

ORCID IDs: 0000-0001-7109-3708 (Nath), 0000-0003-3160-2277 (Szécsi), 0000-0002-0100-0278 (Csehi), 0000-0002-1654-5596 (Mednyánszky), 0000-0003-3344-5308 (Kiskó), 0000-0002-8617-9659 (Bányai), 0000-0002-7249-9328 (Dernovics), 0000-0002-2284-8139 (Koris) 


\section{Introduction}

Leguminous soybean (Glycine max) is considered the largest edible protein source around the world (1). After wet milling of soybean seed, the main by-product soybean meal is generated, which is an abundant by-product of vegetable oil processing industries (2). Soybean meal contains $40-45 \%$ (on mass basis) protein and its application is mostly limited to broiler and fish feed $(3,4)$. It is well documented that functionality of plant proteins, including soy proteins, depends on amino acid sequence, their composition and digestibility. Although trypsin inhibitor activity is adequately reduced by the heat treatment during the production of soybean meal, the allergenic effect of soybean meal proteins renders this by-product an inadequate source of essential amino acids (5). To avoid this problem, production of hypoallergenic low-molecular-mass (LMM) peptides (protein hydrolysate) from defatted soybean meal is considered a reliable approach $(6,7)$.

In many cases, acid hydrolysis is used to reduce the content of soybean allergens $(8,9)$. For food-grade peptide production, concentrated hydrochloric acid treatment is not acceptable because of the formation of toxic compounds, such as 3-chloro-1,2-propane-diol and 1,3-dichloro-2-propanol (10). Therefore, enzymatic digestion is preferred because it can be controlled by the selection of specific enzymes and reaction conditions. Moreover, enzymatic digestion upgrades several functional properties and it can reduce the allergenicity of protein-based products $(11,12)$. However, it must be noted that enzymatic treatment alone cannot definitely reduce the allergenicity of soy proteins (13).

Conventionally, batch bioreactors have been used for the hydrolysis of plant proteins, including soy protein (14-19). Recently, some research groups have reported the application of membrane-integrated bioreactor for the production of angiotensin I-converting enzyme inhibitory peptides (20), antioxidant peptides $(21,22)$ and anti-adipogenic peptides (23-25) from soy protein. To implement the membrane-integrated bioreactor on industrial scale for the production of bioactive compounds from soybean, it is clear that more systematic and judicious investigations with technological viewpoints are required. Methodical experiments with bench scale setup are a prerequisite to transfer the laboratory-developed technology to industrial scale. In our investigation, hypoallergenic antibacterial LMM peptides were produced from defatted soybean meal with an in-house developed membrane bioreactor, which is the first such attempt to the best of our knowledge. Several advantages of the membrane bioreactor are well documented, e.g. it is efficient for the separation of target product molecule and enzyme from the reaction broth and it also allows the reuse of the enzyme (26).

In the first step of our experiments, defatted soybean meal was subjected to tryptic digestion in the bioreactor, operated in batch mode. Initial soybean meal concentration $\left(\gamma_{\mathrm{sm}_{\mathrm{o}}}\right)$, reaction temperature and $\mathrm{pH}$ were varied under fixed agitation speed to optimize the enzymatic reaction. After the tryptic digestion, LMM peptides were purified in a series of cross-flow filtration processes based on size exclusion. Suspended solids were removed from the reaction broth by cross-flow flat sheet nylon prefiltration membrane (pore size $100 \mu \mathrm{m}$ ). LMM peptides were purified from the clarified reaction broth by cross-flow filtration using tubular ceramic ultrafiltration (UF) membrane (molecular mass cut-off (MMCO) $5 \mathrm{kDa}$ ). To diminish the concentration polarization near the prefiltration membrane surface, constant transmembrane pressure (TMP) of $3 \cdot 10^{5} \mathrm{~Pa}$ was applied, whereas during LMM peptide purification with UF membrane, different TMPs and the use of a static turbulence promoter, a mechanical device promoting high shear on membrane surface, were considered. To obtain more purified LMM peptides, 4-stage discontinuous diafiltration with intermediate cleaning and volume concentration factor (VCF) of 2 were used.

Molecular mass of LMM peptides $(M<5 \mathrm{kDa})$ in UF permeate was determined by sodium dodecyl sulfate polyacrylamide gel electrophoresis (SDS-PAGE) and liquid chromatography-electrospray ionization quadrupole time-of-flight mass spectrometry (LC-ESI-Q-TOF-MS). Efficiency of the removal of allergenic proteins or peptide sequences was quantified by an enzyme-linked immunosorbent assay (ELISA) method and characterized with LC-ESI-Q-TOF-MS-based bottom-up sequencing. The effects of purified LMM peptides on Bacillus cereus and Pediococcus acidilactici HA6111-2 were also investigated together with the quantification of antioxidant capacity that might be related to the promotion of bacterial growth.

\section{Materials and Methods}

\section{Defatted soybean meal}

Defatted soybean meal was kindly supplied by Pannon Vegetable Oil Production Ltd. (Foktő, Hungary).

\section{Chemicals and reagents}

Lyophilized trypsin from bovine pancreas $(\geq 27.78$ units per $\mathrm{mg}$ of solid at $25^{\circ} \mathrm{C}$ ), Tris-(hydroxymethyl)-aminomethane ( $\geq 99.8 \%$ ), sodium acetate (anhydrous, $\geq 99 \%$ ), lithium citrate $(\geq 99.5 \%)$, lithium chloride ( $\geq 99 \%$ ), lithium hydroxide $(\geq 99 \%)$, citric acid $(\geq 99.5 \%)$, sodium diphosphate $(\geq 99 \%), \beta$-casein from bovine milk ( $\geq 98 \%$ ), trichloroacetic acid $(\geq 99 \%)$, thiodiglycol $(\geq 99 \%)$, ninhydrin $(\geq 99$ $\%)$, hydrindantin (98\%), 2-methoxyethanol (99.8\%), bovine serum albumin ( $\geq 96 \%$ ) and 2,4,6-Tris(2-pyridyl)-s-triazine ( $\geq 98 \%$ ) were obtained from the Sigma-Aldrich group (Schnelldorf, Germany). Acetonitrile (HPLC gradient grade) and formic acid (98-100\%) were purchased from VWR International (Radnor, PA, USA). Sulfuric acid (96\%) and sodium hydroxide, boric acid, potassium sulfate, titanium dioxide and copper sulfate (all $>98.5 \%$ ) were purchased from Reanal (Budapest, Hungary). Ultrasil P3-11 was procured from Ecolab-Hygiene $\mathrm{Kft}(\mathrm{Bu}-$ dapest, Hungary). Ferric chloride (99\%), ascorbic acid $(99.7 \%)$, sodium carbonate $(\geq 99.99 \%)$, sodium dihydrogen phosphate ( $99 \%)$, disodium hydrogen phosphate $(\geq 99 \%)$, dipotassium hydrogen phosphate $(\geq 99 \%)$, potassium dihydrogen phosphate $(\geq 99.5 \%)$, sodium chloride $(\geq 99.5 \%)$, sodium potassium tartrate $(99 \%)$, soybean casein digestive medium and agar powder were purchased from Merck (Darmstadt, Germany). Folin-Ciocalteu reagent was pur- 
chased from G-Biosciences (Maryland Heights, MO, USA). An enzyme-linked immunosorbent assay (ELISA) kit for the quantification of soy allergens was purchased from Neogen (Veratox 8410; Neogen Corporation, Lansing, MI, USA). Milli-Q ultrapure deionized water $(18.2 \mathrm{M} \Omega \cdot \mathrm{cm}$; Merck-Millipore, Molsheim, France) was used throughout the experiment.

\section{Experimental setup}

In this study, an in-house built membrane bioreactor, i.e. a bioreactor with a series of external membrane separation units, was used for low-molecular-mass (LMM) peptide production from defatted soybean meal. The schematic diagram of the experimental setup is shown in Fig. 1.

In detail, a 2.5-litre jar bioreactor (working volume 1 L) was used for the enzymatic digestion of soybean meal proteins. The bioreactor was equipped with a single pitched flat-blade turbine. Two probes were placed into the bioreactor for measuring $\mathrm{pH}$ and temperature during the enzymatic reaction. The reactor had a water jacket and it was fitted with a thermostat. A cross-flow flat-plate membrane module (length $220 \mathrm{~mm}$, width $120 \mathrm{~mm}$ and height $60 \mathrm{~mm}$ ), made of stainless steel (SS316), was attached to the bioreactor externally. Three flat-sheet nylon prefiltration membranes were placed inside the module. The dimensions of a single prefiltration membrane were: length $200 \mathrm{~mm}$, width $100 \mathrm{~mm}$, thickness $150 \mu \mathrm{m}$, active filtration area $1.4 \cdot 10^{-2} \mathrm{~m}^{2}$ and pore size $100 \mu \mathrm{m}$. The permeate end of the prefiltration membrane unit was attached to the temperature-controlled storage tank. Another cross-flow single-channel tubular membrane module, made of stainless steel (SS316), was fitted with the storage tank. Inside that membrane module, a tubular ceramic ultrafilter (UF) membrane with the molecular mass cut-off (MMCO) of 5 kDa (Membralox ${ }^{\circledR}$ T1-70; Pall Corporation, Crailsheim, Germany) was placed. The active layer and support layer of the membrane were titanium oxide and aluminium oxide, respectively. The length, inner and outer diameters were 250,7 and $10 \mathrm{~mm}$, respectively, and active filtration area was $5 \cdot 10^{-3} \mathrm{~m}^{2}$. Transmembrane pressures (TMPs) of both types of membrane modules were monitored by pressure gauges and flow control valves, fitted at the two opposite ends of the membrane modules. Feed flow rates were controlled using hydraulic diaphragm pumps (Hydra-Cell G03; Verder Hungary Kft., Budapest, Hungary) and the inlet and outlet flow valves. A rotameter at the retentate end and a bypass valve were also used for controlling the flow rate in the UF membrane module. Stainless steel twisted tape static turbulence promoter was placed inside the ceramic membrane tube to create turbulence on the membrane surface. The promoter had an aspect ratio $O_{\mathrm{tp}}=2$, diameter $d_{\mathrm{tp}}=6.5 \mathrm{~mm}$, total length $l_{\mathrm{tp}}=241 \mathrm{~mm}$, pitch length $l_{\mathrm{e}}=13.2 \mathrm{~mm}$, number of mixing elements $N_{\mathrm{TP}}=36$ and thickness $\delta_{\mathrm{TP}}=1.2 \mathrm{~mm}$.

\section{Methods}

Tryptic digestion of defatted soybean meal and membrane-based separation of LMM peptides

Prior to the experiment, defatted soybean meal powder with particle size of approx. $200 \mu \mathrm{m}$ was prepared in a laboratory ball mill (MM 400; Retsch Technology, Haan, Germany). Tryptic digestion was carried out using free (i.e. non-immobilized) trypsin in a bench-top bioreactor, operated in batch mode. Buffered suspension of the soybean meal at appropriate concentration was prepared for enzymatic reaction and then the substrate was preincubated under fixed operational temperature of $40{ }^{\circ} \mathrm{C}$. After preincubation, a fixed concentration of enzyme $(0.14 \mathrm{~g} / \mathrm{L})$ was added into the reaction medium to initiate the enzymatic hydrolysis. The reaction was performed under fixed agitation speed of $175 \mathrm{rpm}$ and programmed operating conditions up to $4 \mathrm{~h}$. To optimize the enzymatic digestion, initial concentration of soybean meal $\left(\gamma_{\mathrm{sm}_{0}}\right)$, reaction temperature and $\mathrm{pH}$ were varied in the range of $25-100 \mathrm{~g} / \mathrm{L}, 25-60^{\circ} \mathrm{C}$ and $6.0-11.0$, respectively. The $\mathrm{pH}$ of the reaction medium was maintained at 6.0, 7.0 and 8.011.0 with $50 \mathrm{mM}$ of phosphate-citrate buffer, sodium phosphate buffer and Tris buffer, respectively. Isothermal conditions during enzymatic reaction were maintained with circulating water (warm/cold) through the jacket of the bioreactor. After $4 \mathrm{~h}$ of enzymatic reaction, $800 \mathrm{~mL}$ of the reaction broth were pumped and pretreated with a

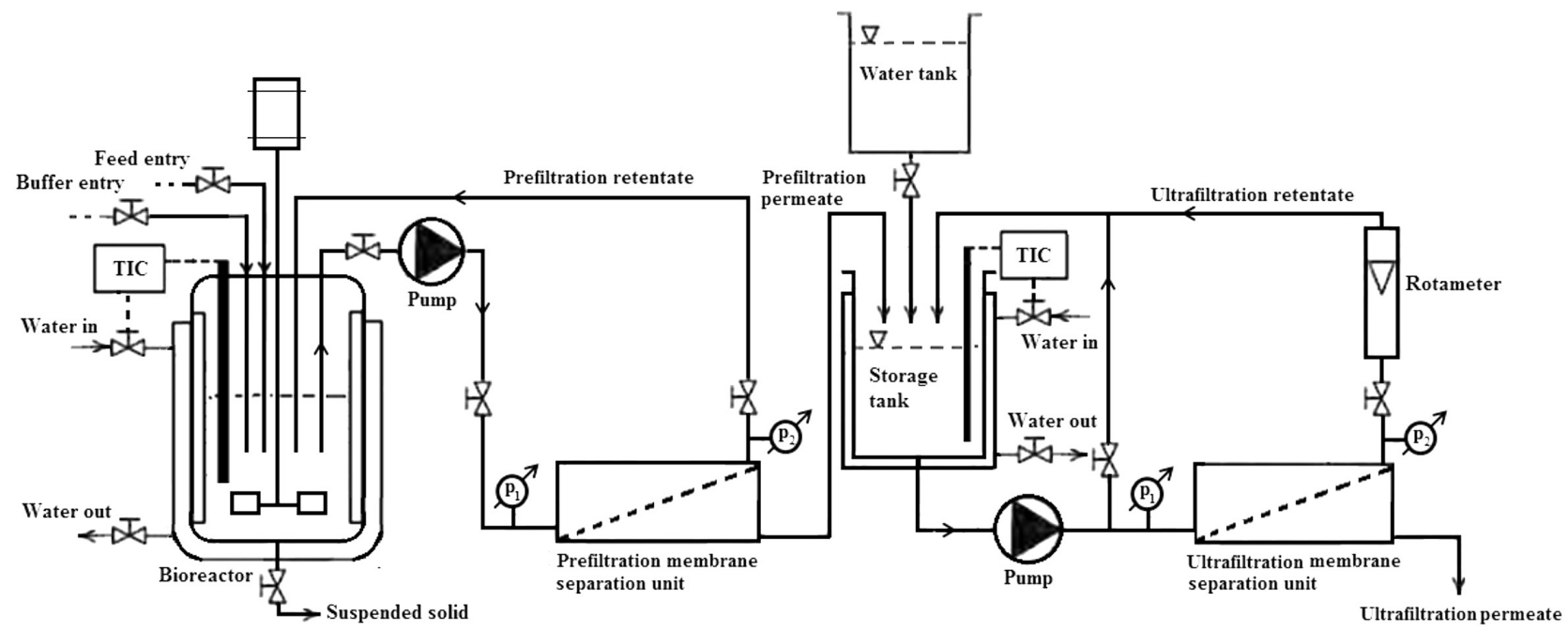

Fig. 1. Schematic diagram of the experimental setup. TIC=temperature indicator controller, $p_{1}$ and $p_{2}$ are pressure gauges 
cross-flow prefiltration membrane separation process with retentate recirculation. Suspended solids from the reactor were drained properly after each experiment. The permeate of prefiltration membrane was used for isolation of LMM peptides $(M<5 \mathrm{kDa})$ by a tubular cross-flow UF membrane. In this case, LMM peptides were passed through the porous channel of the UF membrane as permeate, whereas trypsin $(M=24 \mathrm{kDa})$ and residual high-molecular-mass peptides $(M>5 \mathrm{kDa})$ were rejected. To reduce the concentration polarization near the prefiltration membrane surface, constant operational TMP of $3 \cdot 10^{5}$ Pa was used. On the other hand, to optimize the purification process of LMM peptides in UF membrane, different TMPs, ranging from $2-5 \cdot 10^{5} \mathrm{~Pa}$, and a static turbulence promoter were used. During filtration with UF membrane, constant retentate flow rate $\left(Q_{R}\right)$ of $100 \mathrm{~L} / \mathrm{h}$ was maintained. In order to obtain more purified LMM peptides, four stages of discontinuous diafiltration with intermediate cleaning and constant volume concentration factor (VCF) of 2 were adopted during separation in UF membrane.

Estimation of the degree of hydrolysis and kinetic constants of enzymatic hydrolysis of soybean meal protein

For each set of enzymatic hydrolyses, samples were withdrawn from the bioreactor through a capillary needle in 1-hour intervals throughout the whole hydrolysis period. Samples were evacuated into sample tubes and were immediately placed in a water bath at $90{ }^{\circ} \mathrm{C}$ to inactivate the enzyme. Temperature of the sample was reduced to $25^{\circ} \mathrm{C}$ in a water bath (Precision COL 19; Thermo Scientific $^{\mathrm{TM}}$, Waltham, MA, USA), and $5 \mathrm{~mL}$ of $200 \mathrm{~g} / \mathrm{L}$ of trichlorocacetic acid were added to the $5 \mathrm{~mL}$ of the sample. The mixture was left to stand in the water bath at 25 ${ }^{\circ} \mathrm{C}$ for $30 \mathrm{~min}$ to allow precipitation. Subsequently, the sample was centrifuged at $2800 \times g$ (Z206A; Hermle, Wehingen, Germany) at $20{ }^{\circ} \mathrm{C}$ for $30 \mathrm{~min}$. If the $\mathrm{pH}$ of the supernatant was below 7.0, $1 \mathrm{~mol} / \mathrm{L}$ of sodium hydroxide was used to neutralize it $(\mathrm{pH}=7.0)$. Protein concentrations in the sediment and supernatant were determined by the Kjeldahl method according to the ISO 20483:2013 (27) and the Lowry assay (28), respectively. Degree of hydrolysis $(\mathrm{DH})$ (in \%) of soybean meal protein was calculated according to the following equation:

$$
\mathrm{DH}=\frac{\left(\gamma_{\mathrm{sp}_{\mathrm{i}}}-\gamma_{\mathrm{sp}_{0}}\right)}{\gamma_{\mathrm{s}_{0}}} \cdot 100
$$

where $\gamma_{\mathrm{sp}_{1}}$ is the concentration of soluble protein at any time in $10 \%$ of trichlorocacetic acid $(\mathrm{g} / \mathrm{L}), \gamma_{\mathrm{sp}_{0}}$ is the concentration of soluble protein at initial time in $10 \%$ of trichlorocacetic acid (g/L) and $\gamma_{s_{0}}$ is the initial protein concentration in substrate $(\mathrm{g} / \mathrm{L})(29)$.

To estimate the maximum reaction velocity $\left(v_{\max }\right)$, inhibition constant $\left(K_{\mathrm{s}}\right)$ and the half-saturation constant $\left(K_{\mathrm{m}}\right)$, nonlinear regression analysis was performed with initial enzymatic hydrolysis reaction rate $\left(r_{0}\right)$ and corresponding substrate concentration $\left(\gamma_{\mathrm{s}}\right)$ :

$$
r_{0}=\frac{v_{\max } \cdot \gamma_{\mathrm{s}}}{K_{\mathrm{m}}+\gamma_{\mathrm{s}}+\frac{\gamma_{\mathrm{s}}^{2}}{K_{\mathrm{s}}}}=\frac{k_{\mathrm{cat}} \cdot \gamma_{\mathrm{E}} \cdot \gamma_{\mathrm{s}}}{K_{\mathrm{m}}+\gamma_{\mathrm{s}}+\frac{\gamma_{\mathrm{s}}^{2}}{K_{\mathrm{s}}}}
$$

where $k_{\text {cat }}$ is turnover number $(1 / \mathrm{h})$ and $\gamma_{\mathrm{E}}$ is enzyme concentration $(\mathrm{g} / \mathrm{L})(30)$.

The Arrhenius equation (Eq. 3) was considered to estimate the apparent activation energy $\left(E_{\mathrm{a}}\right)$ of enzymatic reaction. Logarithm values of $k_{\text {cat }} v s$. reciprocal of temperature difference were used to estimate the $E_{\mathrm{a}}$ of enzymatic reaction. In the proposed investigation, reference temperature $T^{*}=298 \mathrm{~K}$ was considered:

$$
k_{\text {cat }}=k_{\mathrm{a}} \cdot \exp \left(-\frac{E_{\mathrm{a}}}{R} \cdot\left[\frac{1}{T}-\frac{1}{T^{*}}\right]\right)
$$

where $k_{\mathrm{a}}$ is the constant of activation energy $(1 / \mathrm{h}), R$ is ideal gas constant $(\mathrm{kJ} /(\mathrm{K} \cdot \mathrm{mol}))$ and $T$ is reaction temperature $(\mathrm{K})(31)$.

Estimation of thermodynamic constants of enzymatic reaction

In order to estimate the free energy change of the activation of enzymatic reaction $\left(\Delta G^{*}\right)$, transition state theory was considered (32). The Eyring's absolute rate equation was adopted for this purpose:

$$
\Delta G^{*}=-R \cdot T \cdot \ln \left(\frac{k_{\mathrm{cat}} \cdot h}{K_{\mathrm{B}} \cdot T}\right)
$$

where $h$ is Planck's constant (Js) and $K_{\mathrm{B}}$ is Boltzmann constant $(\mathrm{J} / \mathrm{K})(31)$.

The activation enthalpy of enzymatic reaction $\left(\Delta H^{*}\right)$ was estimated using the following equation (31):

$$
\Delta H^{*}=E_{\mathrm{a}}-R \cdot T
$$

The activation entropy of enzymatic reaction $\left(\Delta S^{*}\right)$ was estimated according to the following equation (31):

$$
\Delta S^{*}=\frac{\left(\Delta H^{*}-\Delta G^{*}\right)}{T}
$$

The free energy changes of substrate-enzyme binding $\left(\Delta G_{\mathrm{b}}\right)$ were estimated according to the following equation (31):

$$
\Delta G_{\mathrm{b}}=-2.303 \cdot R \cdot T \cdot \log \frac{\gamma_{0}}{K_{\mathrm{m}}}
$$

where $\gamma_{0}$ is standard concentration of $1 \mathrm{~g} / \mathrm{L}$ (assumption value).

The enzyme-substrate binding enthalpy $\left(\Delta H_{\mathrm{b}}\right)$ and enzyme-substrate binding entropy $\left(\Delta S_{\mathrm{b}}\right)$ were calculated by regression analysis (31):

$$
-\frac{\Delta G_{\mathrm{b}}}{T}=\frac{\Delta H_{\mathrm{b}}}{T}+\Delta S_{\mathrm{b}}
$$

Estimation of membrane permeate flux

Permeate volumes $(V)$ during the UF membrane filtration were collected at constant time $(t)$ intervals. Permeate flux $(J)$ of the UF membrane filtration was calculated according to the following equation:

$$
J=\frac{V}{t \cdot A}
$$

where $A$ is effective membrane surface area $\left(\mathrm{m}^{2}\right)(33)$.

Change of permeate flux $\left(\Delta J_{\mathrm{i}}\right)$ (in \%) in each discontinuous diafiltration stage and TMP was calculated by the following equation during the UF membrane filtration: 


$$
\Delta J_{\mathrm{i}}=\frac{\left(J_{0}-J_{\mathrm{f}}\right)}{J_{0}} \cdot 100
$$

where $J_{0}$ is initial permeate flux $\left(\mathrm{L} /\left(\mathrm{m}^{2} \cdot \mathrm{h}\right)\right)$ and $J_{\mathrm{f}}$ is final permeate flux $\left(\mathrm{L} /\left(\mathrm{m}^{2} \cdot \mathrm{h}\right)\right)$.

\section{Specific energy consumption of the UF membrane} filtration

Pressures at two opposite ends of the UF membrane module were recorded and from these, pressure drop $(\Delta p)$ was calculated. Specific energy consumption $\left(E_{s}\right)$ of the UF membrane filtration was calculated by the following equation (34):

$$
E_{\mathrm{s}}=\frac{Q_{\mathrm{R}} \cdot \Delta P_{\mathrm{m}}}{J_{0} \cdot A}
$$

Rejection of the enzyme by the membrane

The rejection of the enzyme by the UF membrane was calculated according to the following equation:

$$
\text { Rejection }=\frac{\left(\begin{array}{l}
\text { Activity of enzyme in retentate }- \\
\text { Activity of enzyme in permeate }
\end{array}\right)}{\text { Activity of enzyme in retentate }}
$$

Estimation of water permeability through membrane and membrane hydraulic resistance

Before experiments, the membranes were compacted to prevent any possibility of changing the water permeability $\left(L_{\mathrm{p}}\right)$ through the membrane and membrane hydraulic resistance $\left(R_{\mathrm{m}}\right)$ during experimentation. Both types of membranes were compacted under the pressure of $5.5 \cdot 10^{5}$ Pa with Milli-Q water (Merck-Millipore) until the water flux became steady. The $L_{\mathrm{p}}$ was estimated from the slope of water fluxes versus corresponding operational TMPs $\left(1-5 \cdot 10^{5} \mathrm{~Pa}\right)$.

$$
L_{\mathrm{p}}=\frac{J}{\mathrm{TMP}}
$$

In a similar way, $R_{\mathrm{m}}$ was determined according to the Darcy's law for both types of membranes:

$$
J=\frac{\mathrm{TMP}}{\mu \cdot R_{\mathrm{m}}}
$$

where $\mu$ is dynamic viscosity of water (33).

\section{Membrane cleaning}

As the pore size of prefiltration membrane was considerably large, there was low possibility of protein or peptide adsorption on the membrane surface. To clean off the polarization layer on the prefiltration membrane surface, $10 \mathrm{~g} / \mathrm{L}$ of sodium hydroxide solution was used at TMP of $5 \cdot 10^{5} \mathrm{~Pa}$. Subsequently, water cleaning was done at the same operational TMP for $1 \mathrm{~h}$. The UF membrane was cleaned thoroughly for $30 \mathrm{~min}$ with $10 \mathrm{~g} / \mathrm{L}$ of Ultrasil P3-11 (Ecolab-Hygiene Kft) and for $1 \mathrm{~h}$ with $10 \mathrm{~g} / \mathrm{L}$ of citric acid with intermediate water cleaning steps after individual operation steps. Flow rate of $200 \mathrm{~L} / \mathrm{h}$ without any TMP was used during the cleaning with Ultrasil and citric acid, while TMP of $5 \cdot 10^{5} \mathrm{~Pa}$ and a flow rate of $200 \mathrm{~L} / \mathrm{h}$ were used during the cleaning with water. In each case, the water flux was found to regain its original value almost completely (i.e. value of water flux before experiment).
Total protein analysis

Total nitrogen as well as mass concentration of the protein in initial defatted soybean meal $\left(\gamma_{\mathrm{p}}\right)$ were quantified by the Kjeldahl method (27) with a semi-automatic Kjeldahl nitrogen analyzer equipped with a block digestion unit (Kjeldatherm ${ }^{\oplus}$; Gerhardt, Königswinter, Germany). The $\gamma_{\mathrm{sp}}$ in the supernatant of the reaction medium treated with trifluoroacetic acid and LMM peptides in membrane permeate were estimated by the Lowry assay method (28). Bovine serum albumin was used as a standard and colorimetric estimation was performed at the wavelength $\lambda=393 \mathrm{~nm}$ with a UV-Vis spectrophotometer (Evolution $^{\mathrm{TM}}$ 300; Thermo Scientific ${ }^{\mathrm{TM}}$ ).

\section{Determination of tryptic activity}

Activities of trypsin in the UF membrane permeate and retentate fractions were determined by a spectrophotometer (Evolution ${ }^{\mathrm{TM}}$ 300; Thermo Scientific ${ }^{\mathrm{TM}}$ ) using casein as substrate. Enzyme assay was performed with 50 $\mathrm{mM}$ of potassium phosphate buffer, $\mathrm{pH}=7.5$. During enzymatic assay the incubation temperature of $30^{\circ} \mathrm{C}$ was considered. Colorimetric determination was performed at the wavelength $\lambda=660 \mathrm{~nm}$. Activity of the enzyme was expressed in $\mathrm{U} / \mathrm{mL}$ (35).

\section{Free amino acid analysis}

Concentrations of free amino acids $\left(\gamma_{\mathrm{FAA}}\right)$ in the reaction broth and UF membrane permeate were determined with an amino acid analyzer (AAA 400; INGOS s.r.o., Prague, Czech Republic), equipped with an Ionex Ostion LCP5020 ion-exchange column $(200 \mathrm{~mm} \times 3.7 \mathrm{~mm}$; Ionex SG LLC, Davis, CA, USA). To quantify the free amino acid content, $2 \mathrm{~mL}$ of liquid samples (hydrolysis broth and the UF membrane permeate) were mixed with $10 \mathrm{~mL}$ of $10 \%$ (by volume) trichloroacetic acid and incubated for $1 \mathrm{~h}$. Afterwards, the samples were filtered through disposable $0.45-\mu \mathrm{m}$ polytetrafluoroethylene (PTFE) membrane filters (Acrodisc ${ }^{\oplus}$ syringe filters; Sigma-Aldrich, St. Louis, MO, USA). Ninhydrin (20 g/L in 2-methoxyethanol) at the flow rate of $0.25 \mathrm{~mL} / \mathrm{min}$ was used for derivatization purposes in the amino acid analyzer. The instrument was equipped with a UV/Vis detector operating in the range of wavelength $\lambda=440-570 \mathrm{~nm}$. The column temperature was set to $55^{\circ} \mathrm{C}$, and lithium citrate buffer $(\mathrm{pH}=2.70-4.65)$ as mobile phase in a stepwise gradient was used at the flow rate of $0.3 \mathrm{~mL} / \mathrm{min}$. The $\mathrm{pH}$ gradient was set as follows: $0-24 \mathrm{~min}$ at $\mathrm{pH}=3.05,25-49 \mathrm{~min}$ at $\mathrm{pH}=3.50,50-74 \mathrm{~min}$ at $\mathrm{pH}=4.15$, $75-137 \mathrm{~min}$ at $\mathrm{pH}=4.65$ and finally, $138-171 \mathrm{~min}$ at $\mathrm{pH}=$ 2.70 .

\section{Molecular mass distribution of LMM soy peptides}

Sodium dodecyl sulfate-polyacrylamide gel electrophoresis (SDS-PAGE) was performed to estimate the molecular mass of the UF membrane permeate peptides, according to the Laemmli method (36). A vertical gel electrophoresis cell (overall dimensions: width $0.14 \mathrm{~m}$, length $0.22 \mathrm{~m}$, height $0.19 \mathrm{~m}$ ) together with a PowerPac ${ }^{\mathrm{TM}}$ high-current power supplier and a Gel-Doc EZ system (Bio-Rad, Hercules, CA, USA) were used in the experiment. The concentrations of running gel and stacking gel were 150 and $60 \mathrm{~g} / \mathrm{L}$, respectively. Standard protein marker (recombinant proteins, $M=250-2 \mathrm{kDa}$; Precision Plus Pro- 
tein $^{\mathrm{TM}}$ Dual Xtra, Bio-Rad) were used. Constant electrical potential difference of $200 \mathrm{~V}$ was applied during the experiment.

Furthermore, to determine the molecular mass distribution and sequences of the peptides present in UF membrane permeate, LC-ESI-Q-TOF-MS was used. Before LC-MS analysis, $3 \mathrm{~mL}$ of the UF membrane permeate were completed with $165 \mu \mathrm{L}$ of acetonitrile (VWR International). The solution was vortexed, centrifuged for $10 \mathrm{~min}$ at $4100 \times g$ at room temperature (Z206A; Hermle). Solid phase extraction (SPE) was performed with SPE tube (SampliQ C18 Endcapped, 0.5 g, 3 mL; Agilent Technologies, Santa Clara, CA, USA). Prior to the sample loading, SPE tubes were conditioned with $5 \mathrm{~mL}$ of acetonitrile and equilibrated with $10 \mathrm{~mL}$ of 5:95 (by volume) acetonitrile/water solution. After sample loading, tubes were washed with $5 \mathrm{~mL}$ of 5:95 acetonitrile/water solution and eluted with $1 \mathrm{~mL}$ of 80:20 (by volume) acetonitrile/water solution. The eluates were evaporated in a vacuum centrifuge (ScanSpeed Modulspin 32(40), ScanVac; LaboGene, Lynge, Denmark). The residues were dissolved in $1 \mathrm{~mL}$ of 8:92 (by volume) acetonitrile/water solution containing $0.1 \%$ (by volume) formic acid, filtered through $0.22-\mu \mathrm{m}$ disposable PTFE filters (VWR International) and injected in the LC-ESI-Q-TOF-MS system.

For the LC-ESI-Q-TOF-MS experiments, a 6530 Accurate Mass LC-MS system (mass accuracy $<2$ ppm, mass resolution >10000; Agilent Technologies) was used. The ESI-Q-TOF-MS instrument was operated with an Agilent 6220 instrument with a dual ESI ion source in positive ionization mode. An Agilent 1200 high-performance liquid chromatography (HPLC) system, equipped with a Zorbax XDB C18 column $(2.1 \mathrm{~mm} \times 50 \mathrm{~mm} \times 3.5 \mu \mathrm{m}$; Agilent Technologies) was used. HPLC mobile phases consisted of eluent A ( $0.1 \%$ (by volume) formic acid in Milli-Q water; Merck-Millipore) and eluent B (acetonitrile with $0.1 \%$ (by volume) formic acid). The flow rate was kept at $0.35 \mathrm{~mL} / \mathrm{min}$ and the following gradient was used: $0-1$ $\min 8 \% \mathrm{~B}, 1-18 \min$ up to $50 \% \mathrm{~B}, 18-20 \mathrm{~min}$ up to $100 \%$ B, 20-21 min $100 \%$ B, 21-24 min down to $8 \%$ B and 24-29 $\min 8 \%$ B. Experiments with ESI-Q-TOF-MS were carried out at $m / z=100-1700$, while MS/MS experiments were accomplished at $m / z=50-1700$ with automatically fixed collision energies for each peptide (slope $4 \mathrm{~V} / 100 \mathrm{Da}$, offset 2 $\mathrm{V})$ and with the following parameter set: precursor ion isolation in narrow MS/MS mode $(\mathrm{m} / \mathrm{z}=1.3)$, detection frequency $4 \mathrm{GHz}$, fragmentor voltage $150 \mathrm{~V}$, curtain voltage $65 \mathrm{~V}$, flow rate of drying gas $13 \mathrm{~L} / \mathrm{min}$, capillary voltage $800 \mathrm{~V}$, nebulizer pressure $2.75 \cdot 10^{5} \mathrm{~Pa}$ and gas temperature $300{ }^{\circ} \mathrm{C}$. Prior to the experiments, the mass accuracy of the instrument was calibrated with ESI-L low concentration tuning mix (Agilent Technologies). MassHunter B.02.01 with SP3 and MassHunter Qualitative Analysis B.03.01 with SP3 software (Agilent Technologies) were used for data analysis.

Molecular feature extraction software was adopted to determine the molecular mass distribution and sequences of the peptides present in the UF membrane permeates. The initial set values of parameters for the Molecular Feature Extractor (part of MassHunter Qualitative Analysis software) were as follows: target data type: small molecules (chromatographic), peak height: >10 000 counts, ion species: $\mathrm{H}^{+}, \mathrm{Na}^{+}$and $\mathrm{K}^{+}$, charge state: maximum charge of 5 , isotope model: peptides, peak spacing tolerance: $\mathrm{m} / \mathrm{z}=$ $0.0025,+7 \mathrm{ppm}$, compound filters: relative height $\geq 2.5 \%$, absolute height $\geq 5000$ counts, compound ion threshold: two or more ions, retention time window: $0.3-14 \mathrm{~min}$ and $\mathrm{m} / \mathrm{z}>200$. Peak lists obtained from MS/MS spectra were identified using OMSSA (open mass spectrometry search algorithm) v. 2.1.9 (37) and X!Tandem version Sledgehammer (2013.09.01.1) (38). The search was conducted using SearchGUI v. 2.6 .5 (39). Protein identification was conducted against a concatenated target-decoy (40) version of the Glycine max (393 reviewed entries) and Bos taurus (1 reviewed entry for bovine cationic trypsin) complement of the UniProtKB (41) (394 (target) sequences). The decoy sequences were created by reversing the target sequences in SearchGUI. The identification settings were as follows: trypsin with a maximum of two missed cleavages; 10 ppm as MS ${ }^{1}$ and $0.02 \mathrm{Da}$ as $\mathrm{MS}^{2}$ tolerances; variable modifications: oxidation of $\mathrm{M}(+15.994915 \mathrm{Da})$, acetylation of protein $\mathrm{N}$-term $(+42.010565 \mathrm{Da})$, pyrrolidone from $\mathrm{E}$ $(-18.010565 \mathrm{Da})$ and pyrrolidone from $\mathrm{Q}(-17.026549 \mathrm{Da})$. Peptides and proteins were inferred from the spectrum identification results using PeptideShaker v. 1.8.0 (42). Peptide spectrum matches (PSMs), peptides and proteins were validated at a $1 \%$ false discovery rate (FDR), estimated using the decoy hit distribution.

ELISA method for the quantification of soy allergens in powdered soybean meal and membrane permeate

In order to reach the analytical range of $2.5-25 \mathrm{mg}$ of soy protein per $\mathrm{kg}$ of the ELISA kit, sample dilution (up to 2000 -fold) of the soybean meal powder and sample concentrating (up to 6.25-fold) for the UF membrane permeate were carried out according to the manufacturer's instructions. That is, for the dilution, $500 \mathrm{mg}$ of sample were extracted with $1250 \mathrm{~mL}$ of extraction solution and the obtained extract was further diluted with the extraction solution to meet the analytical range. To acquire a concentrated solution, $5 \mathrm{~mL}$ of the UF membrane permeate were mixed with $20 \mathrm{~mL}$ of extraction solution. Colorimetric detection $\left(A_{630 \mathrm{~nm}}\right)$ was performed with a microwell plate reader (DIAReader ELx800G-PC; DIALAB GmbH, Wr. Neudorf, Austria).

\section{Microbiological assay}

Antibacterial activity of the LMM peptides from UF membrane permeate against Gram-positive Bacillus cereus (from the Culture Collection of the Department of Microbiology and Biotechnology [CCDMB], Szent István University, Budapest, Hungary) was investigated with the agar well method. A volume of $100 \mu \mathrm{L}$ of 24 -hour culture of $B$. cereus from liquid broth $\left(6 \cdot 10^{6}\right.$ colony-forming units (CFU)) was spread on the soybean casein digestive agar medium (Merck). Agar wells with the diameter of $5 \mathrm{~mm}$ were filled with $100 \mu \mathrm{L}$ of the UF membrane permeate. Zone of inhibition was measured after $48 \mathrm{~h}$ of incubation at $37^{\circ} \mathrm{C}$.

The possible synergistic effect of the LMM peptides from UF membrane permeate on the growth of Pediococcus acidilactici HA6111-2 (from CCDMB) was investigated. Single microplate wells were filled with $135 \mu \mathrm{L}$ of sterile soybean casein digestive medium (Merck), $135 \mu \mathrm{L}$ of the UF membrane permeate and $30 \mu \mathrm{L}$ of 24 -hour inoculum 
of P. acidilactici HA6111-2 (6·10 CFU). Positive and negative controls were also considered to compare the results. Incubation temperature was set at $30^{\circ} \mathrm{C}$. Microbial growth was measured at the wavelength $\lambda=595 \mathrm{~nm}$ by a microplate reader (Multiskan GO; Thermo Scientific ${ }^{\mathrm{TM}}$ ). Data were recorded at 30-minute intervals for the total microbial growth period of $24 \mathrm{~h}$.

\section{Antioxidant capacity}

Antioxidant capacity of LMM peptides from UF membrane permeate was quantified with the ferric reducing ability of plasma (FRAP) method using a UV-Vis spectrophotometer (Evolution ${ }^{\mathrm{TM}}$ 300; Thermo Scientific ${ }^{\mathrm{TM}}$ ). Ascorbic acid was used as reference and the absorbance was measured at $593 \mathrm{~nm}(43)$.

\section{Statistical analysis}

All experiments were performed in triplicate and the mean value with standard deviation (S.D.) was calculated. Statistical data analysis was conducted using a Microsoft Excel spread sheet (Microsoft Corporation, Redmond, WA, USA) and Minitab statistical software v. 16 (Minitab Inc., State College, PA, USA).

\section{Results and Discussion}

\section{Enzymatic digestion}

Effect of initial concentration of soybean meal

To optimize the enzymatic hydrolysis, different initial concentrations of soybean meal $\left(\gamma_{\mathrm{sm}_{0}}\right)$, ranging from $25-100 \mathrm{~g} / \mathrm{L}$, were used. Taking into account the total concentration of protein $\left(\gamma_{\mathrm{p}}\right)$ in the defatted soybean meal $((41.0 \pm 0.1) \%$, by mass $)$, the substrate range covered approx. $10-41 \mathrm{~g}$ of soybean meal protein per L. In Fig. 2a, soluble protein concentration $\left(\gamma_{\mathrm{sp}}\right)$ in the reaction broth was plotted against time progress for different $\gamma_{\mathrm{sm}_{0}}$.

It is observed that $\gamma_{\mathrm{sp}}$ increases with the increase of $\gamma_{\mathrm{sm}_{0}}$ up to $75 \mathrm{~g} / \mathrm{L}$. Low substrate concentration $\left(\gamma_{\mathrm{s}}\right)$ in reaction medium increases the substrate solubility and reduces the intermolecular agglomeration of enzyme-substrate complex, which facilitates the enzymatic hydrolysis as well as product synthesis. Contradictorily, when $\gamma_{\mathrm{sm}_{0}}>75$ $\mathrm{g} / \mathrm{L}$, enzyme active sites are overloaded with the substrate molecules. A fraction of substrate binds with the active enzyme-substrate complex and produces inactive enzyme-substrate complex, which reduces the initial reaction rate $\left(r_{0}\right)$, and the synthesis of soluble protein and low-molecular-mass (LMM) peptides $(30,31)$. In Fig. $2 \mathrm{~b}$, different $r_{0}$ are plotted against corresponding $\gamma_{\mathrm{sm}_{0}}$. At limited $\gamma_{\mathrm{s}}\left(\gamma_{\mathrm{sm}_{0}}\right.$ $\leq 75 \mathrm{~g} / \mathrm{L}$ ), the relationship between $r_{0}$ and $\gamma_{\mathrm{sm}_{0}}$ is linear and after that it has a decreasing trend. The reasons for this observation have been described above. Accordingly, $\gamma_{\mathrm{sm}_{0}}$ $=75 \mathrm{~g} / \mathrm{L}$ is considered optimum for the enzymatic hydrolysis. After tryptic digestion of $75 \mathrm{~g} / \mathrm{L}$ of soybean meal at $40{ }^{\circ} \mathrm{C}$ and $\mathrm{pH}=9$, the concentration of free amino acids $\left(\gamma_{\mathrm{FAA}}\right)$ in reaction broth was $0.33 \mathrm{~g} / \mathrm{L}$. As trypsin is an endopeptidase and its activity is site-specific, the formation of free amino acids due to tryptic digestion was inherently low compared to the formation of soluble protein and
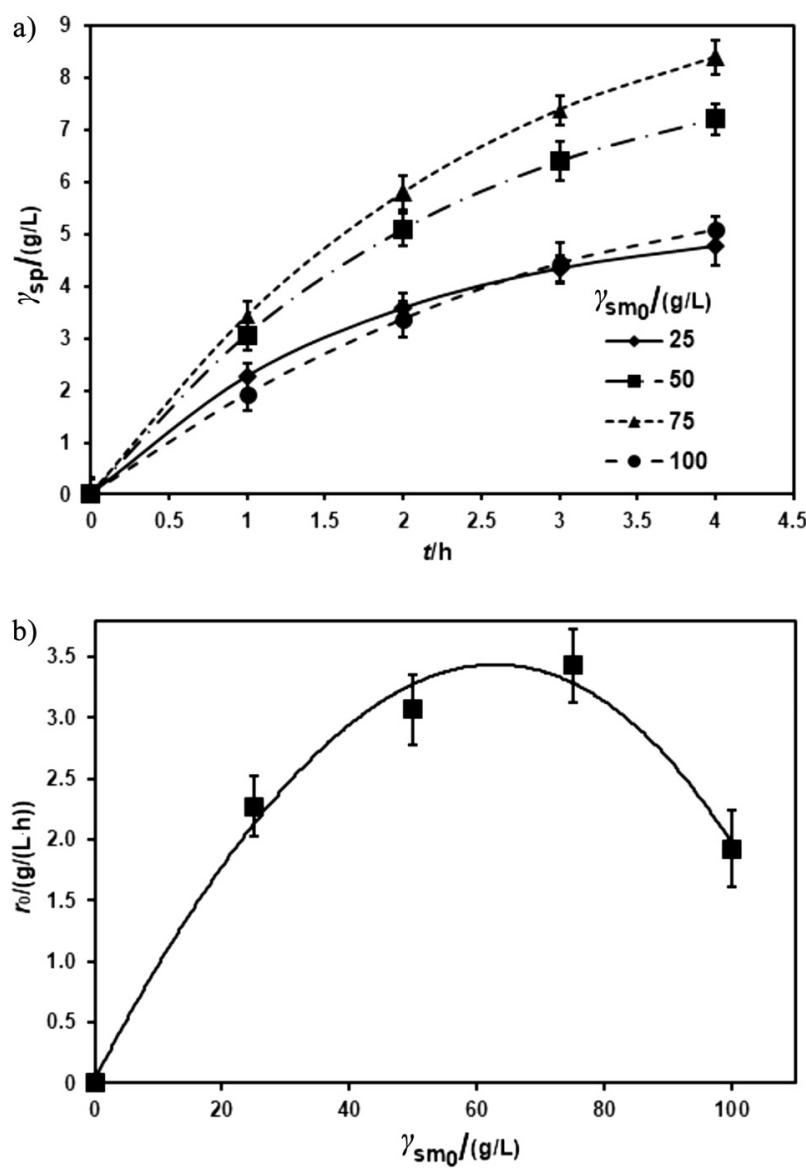

Fig. 2. Changes in: a) mass concentrations of soluble protein in the reaction broth with time, and b) initial enzymatic hydrolysis reaction rate $\left(r_{0}\right)$ of tryptic digestion, using different initial mass concentrations of soybean meal $\left(\gamma_{\mathrm{sm}_{0}}\right)$ at reaction temperature of $40^{\circ} \mathrm{C}$ and $\mathrm{pH}=9.0$

LMM peptides. The $\gamma_{\text {sp }}$ reached $8.4 \mathrm{~g} / \mathrm{L}$ after $4 \mathrm{~h}$ of tryptic digestion of $75 \mathrm{~g} / \mathrm{L}$ of soybean meal at $40^{\circ} \mathrm{C}$ and $\mathrm{pH}=9$.

\section{Effect of temperature}

Effects of temperature and $\mathrm{pH}$ on the enzymatic hydrolysis are shown in Fig. 3. The degree of hydrolysis $(\mathrm{DH})($ in $\%)$ of soybean meal protein increases with the increase of reaction temperature from 25 to $40{ }^{\circ} \mathrm{C}$ and at temperature exceeding $40^{\circ} \mathrm{C}$, it decreases (Fig. 3a).

For a typical enzyme-catalyzed reaction, temperature provides the activation energy, which increases the collision frequency between the enzyme and the substrate, as well as positively influences the turnover number $\left(k_{\text {cat }}\right)$. At a particular temperature, substrate and enzyme come into proximity more frequently and the probability of enzyme and substrate binding increases, which promotes the product formation. With further increase of temperature, enzyme is denatured due to the breakdown of its structural peptide bond or change of its structural configuration $(30,31)$. In other words, substrate solubility increases with the increase of temperature, which facilitates the enzymatic hydrolysis. The $r_{0}$ along with respective reaction temperature is also shown in Fig. 3a. It is noted that $r_{0}$ is maximum at $45{ }^{\circ} \mathrm{C}$ and after that, it has a decreasing trend. The $r_{0}$ and DH (in \%) were calculated based on the 

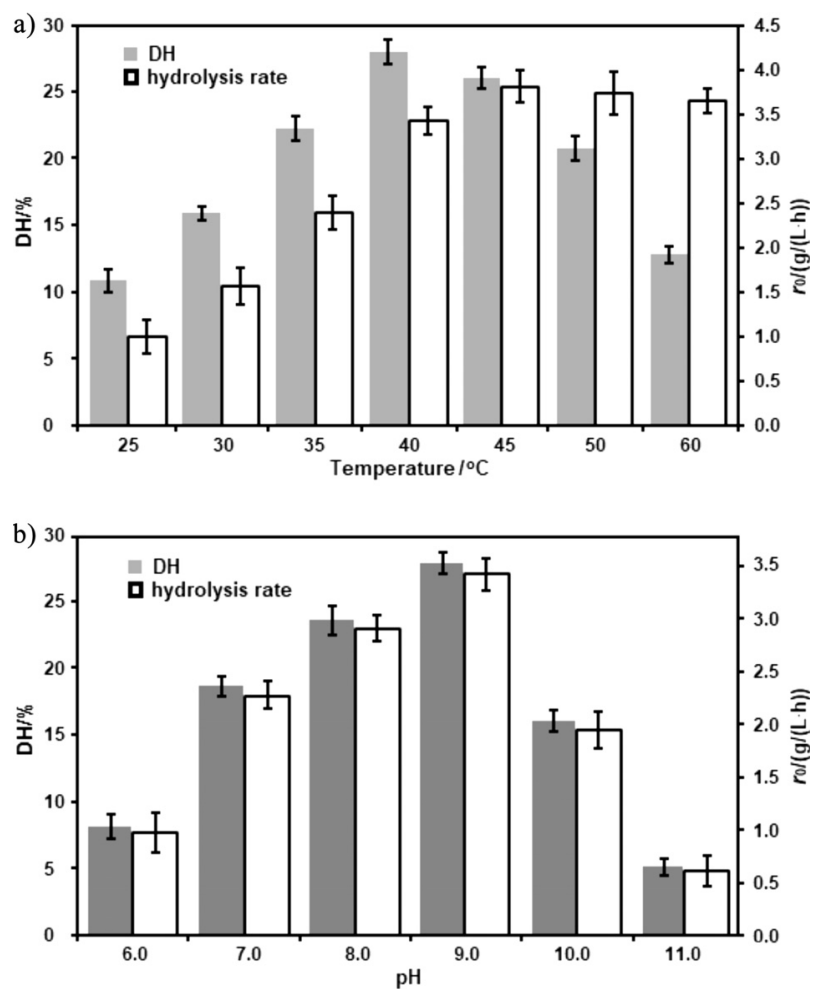

Fig. 3. Degree of hydrolysis (DH) and initial enzymatic hydrolysis reaction rate $\left(r_{0}\right)$ after $4 \mathrm{~h}$ of hydrolysis at: a) different reaction temperatures with initial concentration of soybean meal $\left(\gamma_{\mathrm{sm}_{0}}\right)$ of $75 \mathrm{~g} / \mathrm{L}$ and reaction $\mathrm{pH}=9.0$, and $\left.\mathrm{b}\right)$ different reaction $\mathrm{pH}$ values with initial concentration of soybean meal $\left(\gamma_{\mathrm{sm}_{0}}\right)$ of 75 $\mathrm{g} / \mathrm{L}$ and reaction temperature of $40^{\circ} \mathrm{C}$

formation of soluble protein after 1 and $4 \mathrm{~h}$ of hydrolysis, respectively. The enzyme was active in the initial hydrolysis period (first $1 \mathrm{~h}$ ) and performed well at $45^{\circ} \mathrm{C}$, which is why the $r_{0}$ was high at that temperature. With time progress, enzyme was deactivated and consequently, the $\mathrm{DH}$ was reduced at $45^{\circ} \mathrm{C}$. Similar explanation was given in several cases $(44,45)$. The value of maximum reaction velocity of enzymatic hydrolysis $\left(v_{\max }\right)$ was increased almost 2.6-fold by increasing the temperature from 25 to $40{ }^{\circ} \mathrm{C}$. The values of kinetic constants and thermodynamic parameters of enzymatic hydrolysis are reported in Table 1.

The value of apparent activation energy of enzymatic reaction $\left(E_{\mathrm{a}}\right)$ was determined to be $54.87 \mathrm{~kJ} / \mathrm{mol}$. The change of the free energy $\left(\Delta G^{*}\right)$ and enthalpy $\left(\Delta H^{*}\right)$ of the activation of enzymatic reaction were calculated according to transition state theory (32). Positive values of $\Delta G^{*}$ signify that the free energy change used for the activation of enzymatic reaction is not thermodynamically favoured. All $\Delta G^{*}$ values (Table 1) are almost identical and their order of magnitude is expected for enzyme denaturation (46). Also, large positive values of $\Delta H^{*}$ are characteristic for enzyme denaturation $(32,46-48)$. Negative values of activation entropy of enzymatic reaction $\left(\Delta S^{*}\right)$ are also reported in Table 1 . They signify that the activation of enzymatic reaction is supported by entropy and the thermal deactivation did not entail any significant changes in the secondary and tertiary structure of the enzyme (49). Negative values of $\Delta S^{*}$ are probably due to the compaction of the enzyme molecule and such changes can occur from the formation charge of neighbourhood molecules of enzyme or ordering of the solvent molecules $(32,50)$. The parameter $\Delta H^{*}$ provides the information about the number of broken non-covalent enzyme bonds and $\Delta S^{*}$ provides the information about the net enzyme/solvent disorder change associated with the native structure of the enzyme to a transition state of enzyme configuration $(50,51)$. However, it is very difficult to estimate the number of broken non-covalent bonds required to form the transition state of the enzyme. Finally, the temperature of $40^{\circ} \mathrm{C}$ is considered optimum for enzymatic hydrolysis.

\section{Effect of $\mathrm{pH}$}

The catalytic activity of enzymes depends on the $\mathrm{pH}$ of the medium. The enzyme has ionic (functional) groups in its active site and due to variations of the $\mathrm{pH}$ of the medium, they are ionized in different ways (51). In Fig. 3b, $\mathrm{DH}$ (in \%) of soybean meal protein and $r_{0}$ at corresponding reaction $\mathrm{pH}$ are presented. It is observed that with increase of reaction $\mathrm{pH}$, the $\mathrm{DH}$ (in \%) and $r_{0}$ increase, with their maximum at $\mathrm{pH}=9.0$ and $40{ }^{\circ} \mathrm{C}$. The catalytic site of trypsin is characterized by the catalytic triad Asp 102, His 57 and Ser195 (52). At $\mathrm{pH}=9$, the reaction medium is properly balanced with anionic and cationic ions (groups), which provide the stable ionization of the enzyme, its structural stability and formation of enzyme-substrate complex $(30,31)$. At $\mathrm{pH}>9.0$, the $\mathrm{DH}$ of soybean meal protein decreases. The deactivation process at high alkaline $\mathrm{pH}$ is possibly due to disulfide exchange, which usually occurs at alkaline conditions. Similar explanation was given earlier during pectolytic reaction (53). Naidu and Panda (50) reported that a decrease in enthalpy and en-

Table 1. Reaction kinetic and thermodynamic parameters of the enzymatic hydrolysis

\begin{tabular}{|c|c|c|c|c|c|c|c|}
\hline$\frac{\text { Temperature }}{{ }^{\circ} \mathrm{C}}$ & $\frac{k_{\text {cat }} / K_{\mathrm{m}}}{\mathrm{L} /(\mathrm{g} \cdot \mathrm{h})}$ & $\frac{\Delta G^{*}}{\mathrm{~kJ} / \mathrm{mol}}$ & $\frac{\Delta H^{*}}{\mathrm{~kJ} / \mathrm{mol}}$ & $\frac{\Delta S^{*}}{\mathrm{~kJ} /(\mathrm{mol} \cdot \mathrm{K})}$ & $\frac{\Delta G_{\mathrm{b}}}{\mathrm{kJ} / \mathrm{mol}}$ & $\frac{\Delta S_{\mathrm{b}}}{\mathrm{kJ} /(\mathrm{mol} \cdot \mathrm{K})}$ & $\frac{\Delta H_{\mathrm{b}}}{\mathrm{kJ} / \mathrm{mol}}$ \\
\hline 25 & 0.68 & 87.04 & 52.39 & $-11.63 \cdot 10^{-2}$ & 7.23 & -0.153 & 52.87 \\
\hline 30 & 1.34 & 87.62 & 52.35 & $-11.64 \cdot 10^{-2}$ & 6.56 & & \\
\hline 35 & 2.86 & 88.20 & 52.31 & $-11.65 \cdot 10^{-2}$ & 5.63 & & \\
\hline 40 & 5.33 & 88.78 & 52.27 & $-11.67 \cdot 10^{-2}$ & 4.99 & & \\
\hline
\end{tabular}

$k_{\text {cat }}=$ turnover number of the enzymatic hydrolysis reaction, $K_{\mathrm{m}}=$ half-saturation constant of the enzymatic hydrolysis reaction, $\Delta G^{*}=$ free energy change of the activation of the enzymatic reaction, $\Delta H^{*}=$ activation enthalpy of the enzymatic reaction, $\Delta S^{*}=$ activation entropy of the enzymatic reaction, $\Delta G_{\mathrm{b}}=$ free energy changes of the substrate-enzyme binding, $\Delta S_{\mathrm{b}}=$ enzyme-substrate binding entropy,

$\Delta H_{\mathrm{b}}=$ enzyme-substrate binding enthalpy 
tropy values occurs when $\mathrm{pH}$ of the reaction increases or decreases. According to them, enzyme folds during deactivation. At higher or lower $\mathrm{pH}$ values, the stable three-dimensional structure of enzyme is compressed, resulting in lower enzymatic activity and lower DH. According to the manufacturer (Sigma-Aldrich), the optimum $\mathrm{pH}$ for the proteolytic activity of trypsin is between 7.0 and 9.0. Also, significantly high $\mathrm{DH}$ value (55-75\%) could be obtained during soy protein proteolysis in phosphate buffer due to the enzymatic and non-enzymatic deamidation of the glutamine in soy protein hydrolysate (54). In this investigation, it was found that $\mathrm{DH}$ increased 1.5-fold with changing the reaction $\mathrm{pH}=7$ to $\mathrm{pH}=9$. The down-regulated hydrolysis at $\mathrm{pH}=7.0$ might be due to the presence of some residual trypsin inhibitors in soybean meal $(55,56)$, which act in the presence of phosphate buffer at $\mathrm{pH} 7(57,58)$. The optimum $\mathrm{pH}$ for the hydrolysis is considered to be $\mathrm{pH}=9.0$.

Taking into account the total protein concentration $\left(\gamma_{\mathrm{p}}\right)$ in the actual experiment (approx. $30.8 \mathrm{~g}$ of protein in $75 \mathrm{~g} / \mathrm{L}$ of soybean meal), DH (in \%) of soybean meal protein was found to be approx. $28 \%$ after $4 \mathrm{~h}$ of enzymatic hydrolysis at $40{ }^{\circ} \mathrm{C}$ and $\mathrm{pH}=9.0$. Kong et al. (15) reported that $\mathrm{DH}$ was found to be $9 \%$ when $50 \mathrm{~g} / \mathrm{L}$ of isolated soy protein were treated with trypsin (enzyme/substrate $=0.025$ ) for $3 \mathrm{~h}$ at $55{ }^{\circ} \mathrm{C}$ and $\mathrm{pH}=7.0$. Xie et al. (16) reported that $\mathrm{DH}$ was $22 \%$ when $120 \mathrm{~g} / \mathrm{L}$ of defatted soybean meal were treated with a combination of Protamex and trypsinase (enzyme/substrate=0.01). Enzymatic hydrolysis was performed at $56.78^{\circ} \mathrm{C}$ and $\mathrm{pH}=6.10$ for $10.72 \mathrm{~h}$. In another case, $\mathrm{DH}$ was found to be $10.5 \%$ when $30 \mathrm{~g} / \mathrm{L}$ of isolated soy protein were hydrolyzed with trypsin (enzyme/substrate $=0.025$ ) at $37{ }^{\circ} \mathrm{C}$ and $\mathrm{pH}=7.5$ for $4 \mathrm{~h}(20)$. As the $\mathrm{DH}$ of proteinaceous substance depends on the type of enzyme, the presence of peptide bonds in the substrate, hydrolysis time, reaction temperature and $\mathrm{pH}$, and the analytical methods of estimating $\mathrm{DH}$, the results are not directly comparable in all cases.

\section{Separation of LMM peptides by membrane technology}

Ultrafiltration (UF) membrane was used for fine-tuned separation of LMM peptides from prefiltration membrane permeate. A great emphasis was placed on optimization of the UF membrane separation. After membrane compaction, $R_{\mathrm{m}}$ and $L_{\mathrm{p}}$ values of 5-kDa MMCO membrane were determined to be $3 \cdot 10^{13} \mathrm{~m}^{-1}$ and $3.3 \cdot 10^{-4} \mathrm{~L} /\left(\mathrm{m}^{2} \cdot \mathrm{h} \cdot \mathrm{Pa}\right)$, respectively. In all cases, more than $99 \%$ correlation coefficients were achieved.

In a typical pressure-driven size-exclusion filtration, permeation is strongly influenced by the applied pressure on the membrane surface and diafiltration stage. Permeate flux $(J)$ curves of 5-kDa UF membrane, without and with a static turbulence promoter under a constant TMP $\left(\mathrm{TMP}=4 \cdot 10^{5} \mathrm{~Pa}\right)$ are shown in Figs. $4 \mathrm{a}$ and $\mathrm{b}$, respectively.

It is observed that in the 1st discontinuous diafiltration stage, $J$ declines rapidly, then gradually and eventually becomes steady with time. Similar trends at other TMPs were observed (results not shown). As the concentrations of unhydrolyzed proteins or peptides $(M>5 \mathrm{kDa})$ in the storage tank were high, the concentration polarization, created by unhydrolyzed proteins or peptides on membrane surface, was more rapid in the 1st than in other discontinuous diafiltration stages. The $J$ increased with the increase of discontinuous diafiltration stages because the filtration was performed in discontinuous diafiltration mode with VCF of 2 and intermediate cleaning after every discontinuous diafiltration stage. It was found that the application of the static turbulence promoter enhances the permeation in each discontinuous diafiltration stage and it was almost similar in the 3rd and 4th discontinuous diafiltration stages. Furthermore, it was also noted that the rate of $J$ decline is low in filtration with UF membrane and static turbulence promoter. Static turbulence promoter increases the tangential velocity of fluid across the membrane surface, which increases the turbulence and vorticity of fluid near the membrane surface. As a result, the concentration polarization near the membrane surface is reduced and permeation flux through the membrane pores increases. Furthermore, static turbulence promoter provides the centrifugal force on the fluid, which contributes to the driving force on the membrane surface. Due to the driving force in the presence of the static turbulence promoter, membrane gel layer resistance is reduced and $J$ is increased. According to Figs. $4 a$ and $b$, maximum $J$ decline is in the first stage of filtration. Therefore, the effect of TMP on permeation in the 1st discontinuous diafiltration stage is shown in Fig. 4c, where the final permeate flux $\left(J_{\mathrm{f}}\right)$ and reduction of permeate flux $\left(\Delta J_{\mathrm{i}}\right)$ (in \%) in the 1st discontinuous diafiltration stage are plotted against corresponding operational TMP. It is observed that $J_{\mathrm{f}}$ increases with the increase of operational TMP $\left(\mathrm{TMP}=2-4 \cdot 10^{5} \mathrm{~Pa}\right)$, and after $\mathrm{TMP}=4 \cdot 10^{5} \mathrm{~Pa}$, there is no significant change in the $J_{\mathrm{f}}$. With the increase of operational $\mathrm{TMP}$, more driving force is applied on the membrane surface, which is the cause of low deposition of solute molecules near the membrane surface and higher permeation. At high operational TMPs (TMP $=4 \cdot 10^{5}$ and $\left.5 \cdot 10^{5} \mathrm{~Pa}\right), J$ reaches a constant value, designated as 'limiting flux' of membrane separation. This result might be the cause of: (i) saturation of concentration polarization layer near the membrane surface, as well as constant gel layer resistance (59), (ii) formation of a dynamic secondary membrane near the membrane surface due to high solvent permeation, and consequently thicker solute concentration on the membrane surface and point of incipient solute precipitation (60), (iii) osmotic pressure of the working solution is approximately equal to the applied pressure (61), and (iv) hydrodynamic resistance by boundary layer at high solute concentration on the membrane surface (62). In a similar way, the $\Delta J_{i}$ (in \%) decreases with the increase of TMP and it becomes similar at TMP $=4 \cdot 10^{5}$ and $5 \cdot 10^{5} \mathrm{~Pa}$. In Fig. $4 \mathrm{~d}$, final $J_{\mathrm{f}}$ and $\Delta J_{\mathrm{i}}$ (in \%) in each discontinuous diafiltration stage during the UF membrane separation are plotted against the corresponding discontinuous diafiltration stage, with $\mathrm{TMP}=4 \cdot 10^{5} \mathrm{~Pa}$. It is observed that the $J_{\mathrm{f}}$ increases with the increase of discontinuous diafiltration stage. Consequently, the $\Delta J_{\mathrm{i}}$ (in \%) decreases with increase of the number of discontinuous diafiltration stages and in the 3rd and 4th discontinuous diafiltration stages, they become almost equal. Due to the dilution of the feed sample in storage tank before each discontinuous diafiltration and intermediate cleaning of the membrane after each diafiltration stage, $J$ increases with the increase of the num- 

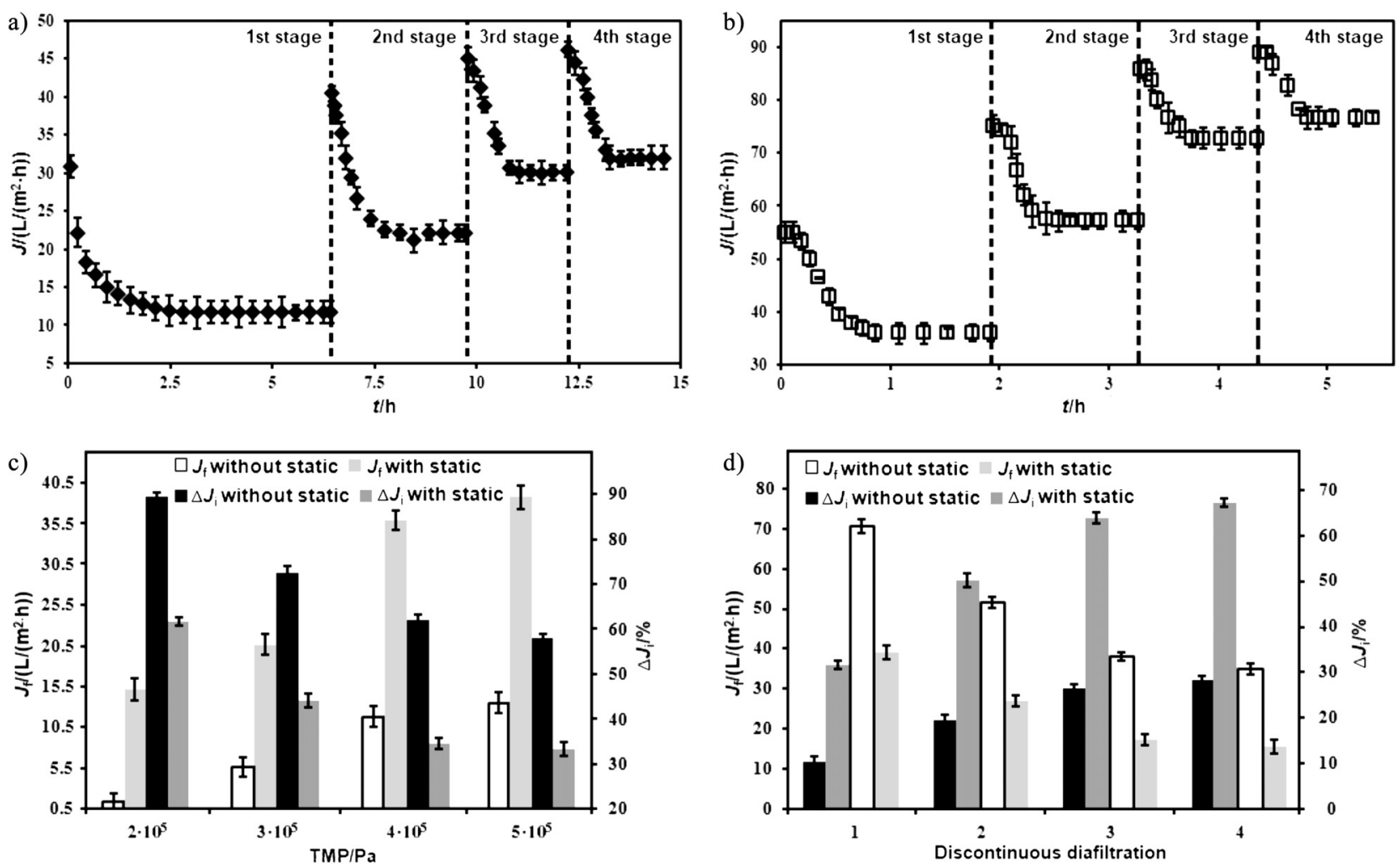

Fig. 4. Permeate flux $(J)$ at transmembrane pressure (TMP) of $4 \cdot 10^{5}$ Pa with discontinuous diafiltration: a) without and b) with a static turbulence promoter during ultrafiltration (UF), c) final permeate flux $\left(J_{\mathrm{f}}\right)$ and change of permeate flux $\left(\Delta J_{\mathrm{i}}\right.$ in $\left.\%\right)$ at the 1 st discontinuous diafiltration stage at different TMPs during UF, and d) final permeate flux $\left(J_{\mathrm{f}}\right)$ and change of permeate flux $\left(\Delta J_{\mathrm{i}}\right.$ in $\left.\%\right)$ at different discontinuous diafiltration stages at $\mathrm{TMP}=4 \cdot 10^{5} \mathrm{~Pa}$ during UF

ber of discontinuous diafiltration stages. The solute concentration in the storage tank was almost the same in the 3rd and 4th stages of the discontinuous diafiltration, and because of that similar values of $\Delta J_{\mathrm{i}}$ (in \%) were obtained. In all cases, it is observed that static turbulence promoter has a positive influence on $J$.

Several researchers have reported about positive influence of the static turbulence promoter on membrane separation unit and filtration process. Krstić et al. (63) reported that the $J$ improved more than $300 \%$ and the membrane cleaning efficiency also improved due to the incorporation of a static turbulence promoter, specifically with a Kenics static mixer during the microfiltration of skimmed milk. Šereš et al. (64) made a comparison between the filtration with a static turbulence promoter and without such a device during the removal of non-sucrose compounds from sugar syrup. The highest $J$ was achieved at $80^{\circ} \mathrm{C}$, with $Q=400 \mathrm{~L} / \mathrm{h}$ and $\mathrm{TMP}=10 \cdot 10^{5} \mathrm{~Pa}$ without the application of static turbulence promoter. During the filtration with static turbulence promoter, the highest $J$ was achieved at TMP $=6 \cdot 10^{5}-10 \cdot 10^{5} \mathrm{~Pa}$ and $Q<100 \mathrm{~L} / \mathrm{h}$. $J$ increased approx. 65 and $30 \%$ at 70 and $80{ }^{\circ} \mathrm{C}$, respectively, when the static turbulence promoter was used. Moreover, $J$ improvements were reported when Kenics static mixer was used in cross-flow microfiltration of wheat starch suspension (65) and baker's yeast (Saccharomyces cerevisiae) separation (66). Gaspar et al. (67) investigated the effects of geometry of static turbulence promoter on oil-in-water microemulsion preparation. According to them,
Kenics static mixer was a good choice for preparation of oil-in-water microemulsions. Positive influence of the static turbulence promoter on membrane emulsification was also reported by Piacentini et al. (68). Ceramic membrane reactor with a static turbulence promoter was used for municipal wastewater reclamation. Due to the incorporation of the static turbulence promoter, $J$ increased from 70 to $175 \mathrm{~L} /\left(\mathrm{m}^{2} \cdot \mathrm{h}\right)$ and average reduction rate of the chemical oxygen demand (COD) was more than $95 \%$ (69).

Reduction of specific energy consumption $\left(E_{\mathrm{s}}\right)$ with high throughput of any equipment is one of the basic approaches to establishing the concept of 'process intensification'. In Fig. 5a, the effect of the presence or absence of static turbulence promoter in the UF membrane filtration at different TMPs on $E_{\mathrm{s}}$ is presented. The $E_{\mathrm{s}}$ values in the UF membrane filtration with the static turbulence promoter are lower than in the filtration without this device. The reason behind this observation is that the static turbulence promoter provides the tangential velocity of fluid across the membrane surface and the centrifugal force on the fluid. At lower retentate flow rate $\left(Q_{\mathrm{r}} \sim 100 \mathrm{~L} / \mathrm{h}\right)$, the combination of these two effects, concentration polarization on membrane surface and membrane gel layer resistance are reduced, resulting in higher $J$ with insignificant pressure drop at two opposite ends of the membrane $(J$ $\gg \Delta p$ ). The values of $E_{\mathrm{s}}$ in the UF membrane filtration with static turbulence promoter are almost unchanged at operational TMP $=3-5 \cdot 10^{5} \mathrm{~Pa}$. 
In Fig. 5b, $E_{\mathrm{s}}$ values are plotted against different discontinuous diafiltration stages at constant operational $\mathrm{TMP}=4 \cdot 10^{5} \mathrm{~Pa}$. It is observed that in all discontinuous diafiltration stages, $E_{\mathrm{s}}$ in the UF membrane with static turbulence promoter is lower than in the filtration without it. This can be explained by the fact that the fluid velocity near the membrane surface increases due to the feed dilution in successive discontinuous diafiltration stages and the high turbulence, provided by the static turbulence promoter.

The $\gamma_{\mathrm{LMM}_{\text {peptides }}}$ in the UF membrane permeate was determined to characterize the separation characteristics of biomolecules in the UF membrane. In Fig. $6 \mathrm{a}, \gamma_{\mathrm{LMM}_{\text {peptides }}}$ in the permeate side of UF membrane is plotted against corresponding operational TMP for the 1st discontinuous diafiltration stage of filtration. It is observed that $\gamma_{\mathrm{LMM}_{\text {peptides }}}$ in the permeate increases with the increase of operational TMP mostly up to $4 \cdot 10^{5} \mathrm{~Pa}$, and it has similar value at $\mathrm{TMP}=5 \cdot 10^{5} \mathrm{~Pa}$. Furthermore, it is observed that more LMM peptides are permeated when UF membrane filtration with static turbulence promoter is used. This may be justified by the fact that due to high driving force and turbulence on the membrane surface caused by TMP and static turbulence promoter, there is low probability of adsorption of high-molecular-mass peptides $(M>5 \mathrm{kDa})$ on membrane surface. High driving force provides higher convective flux. As the static turbulence promoter provides high shear force on the membrane surface, fluid flows through the membrane channel at higher flow rate and solute dep-
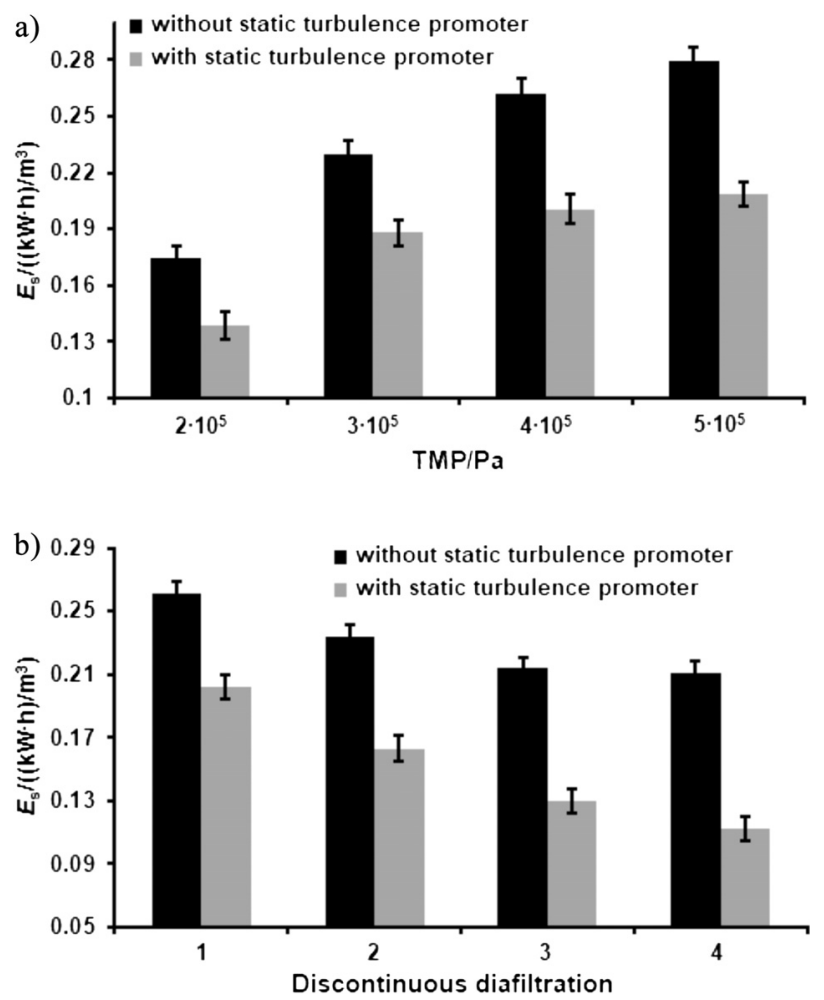

Fig. 5. Specific energy consumption $\left(E_{\mathrm{s}}\right)$ at: a) different transmembrane pressures (TMPs) in the 1st discontinuous diafiltration stage during ultrafiltration (UF), and b) different stages of discontinuous diafiltration with intermediate cleaning at TMP= $4 \cdot 10^{5} \mathrm{~Pa}$ during UF ositions on membrane surface are reduced. As a result, concentration polarization on the membrane surface is reduced and higher amount of LMM peptides passes through the porous membrane. In Fig. $6 \mathrm{~b}, \gamma_{\mathrm{LMM}_{\text {peptides }}}$ in the UF membrane permeate are plotted against the corresponding discontinuous diafiltration stage at constant operational $\mathrm{TMP}=4 \cdot 10^{5} \mathrm{~Pa}$. Most of the LMM peptides permeated in the first discontinuous diafiltration stage and the $\gamma_{\mathrm{LMM}_{\text {peptides }}}$ in the permeate decreased with consecutive discontinuous stages due to the washing effect. Similar trends were observed in other cases also (results not shown). The purpose of using discontinuous diafiltration in this filtration was to obtain more purified LMM peptides.

The cumulative $\gamma_{\mathrm{LMM}_{\text {peptides }}}$ increased with the increase of discontinuous diafiltration stages. By mass balance, the cumulative $\gamma_{\mathrm{LMM}_{\text {peptides }}}$ after the 1st, 2nd and 3rd stages of discontinuous diafiltration were $3.35,4.21$ and $4.38 \mathrm{~g}$ respectively (original values of $\gamma_{\mathrm{LMM}_{\text {peptides }}}$ were 8.33, 2.2 and $0.42 \mathrm{~g} / \mathrm{L}$ in the permeate of the 1st, 2 nd and 3rd stage of diafiltration, respectively) when static turbulence promoter was used with UF at TMP $=4 \cdot 10^{5} \mathrm{~Pa}$.

Taking into account the total $\gamma_{\mathrm{p}}$ in the actual experiment (approx. $30.8 \mathrm{~g} / \mathrm{L}$ of protein per $75 \mathrm{~g} / \mathrm{L}$ of soybean meal), approx. $14 \%$ (by mass) of total protein content could be recovered in the form of LMM peptides. The difference could arise from several sources. First, some proteins cannot be accessed for tryptic digestion because of either the irreversible denaturation caused by heat treat-
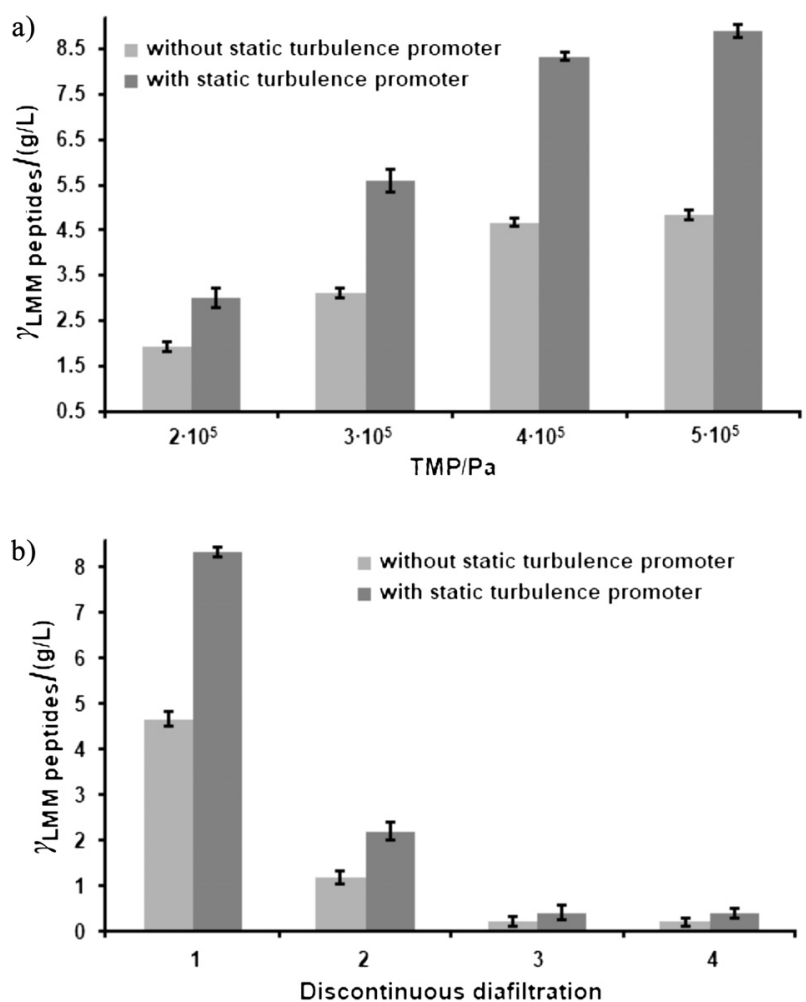

Fig. 6. Mass concentration of low-molecular-mass peptides $\left(\gamma_{\mathrm{LMM}_{\text {peptides }}}\right)$ in the ultrafiltration (UF) membrane permeate at: a) different transmembrane pressures (TMPs) in the 1st discontinuous diafiltration stage, and b) different stages of discontinuous diafiltration with intermediate cleaning at $\mathrm{TMP}=4 \cdot 10^{5} \mathrm{~Pa}$ 
ment during the soybean meal production or the lack of the use of chaotropic agents during digestion. Second, the mass of peptides containing intact disulfide bridges may exceed the cut-off value of the used membrane. For example, the mass of one of the two disulfide-bridged tryptic peptides of an abundant soy protein, glycinin G2 (UniProt no. P04405; linked peptides: EQAQQNECQIQK + IESEGGFIETWNPNNKPFQCAGVALSR, where $\underline{\mathbf{C}}$ indicates bridged cysteine residues) is over $4.4 \mathrm{kDa}$ and clearly exceeds $5 \mathrm{kDa}$ with even one tryptic miscut event. It was examined (in terms of enzymatic activity) that there was no contamination of enzyme in permeate.

Regarding all results shown in Figs. 5 and 6, it may be concluded that a combined strategy, i.e. $\mathrm{TMP}=3 \cdot 10^{5} \mathrm{~Pa}$ and three stages of discontinuous diafiltration with VCF of 2 can be considered optimal for the separation using UF membrane with static turbulence promoter and an effective approach to establish the 'process intensification' concept.

Fig. 7 presents the mass concentrations of individual free amino acids $\left(\gamma_{\mathrm{FAA}}\right)$ in reaction broth and membrane permeates achieved at TMP $3 \cdot 10^{5} \mathrm{~Pa}$ and the 1st discontinuous diafiltration stage.

After enzymatic hydrolysis, the concentration of free amino acids in the reaction broth was $0.33 \mathrm{~g} / \mathrm{L}$, while in the permeate samples obtained with and without the static turbulence promoter it was 0.32 and $0.29 \mathrm{~g} / \mathrm{L}$, respectively. The partial loss of amino acids compared to their source (i.e. reaction broth) was possibly due to the resistance by the concentration polarization layer, created by non-hydrolyzed proteins or high-molecular-mass peptides $(M>5 \mathrm{kDa})$. However, the amount of recovered free amino acids counts for a small part (about $1 \%$ ) of the initial total protein content, their composition carries important information as it is different from the composition, achieved by the complete acidic digestion of soy protein $(70,71)$. While lysine, arginine-derived ornithine, leucine and glutamic acid were the most abundant amino acids in both cases, the abundance of hydroxyproline, the amino acid found in soy cell wall proteins (72), is usually unreported in soybean meal studies (73). This might indicate the relatively higher accessibility of cell wall proteins in defatted soybean meal to tryptic digestion than of the enzymatically hydrolysable and extractable high abundant soy proteins in untreated soybean samples.

\section{Characterization of LMM peptides}

\section{Molecular mass distribution of LMM peptides}

Permeate samples obtained by UF membrane filtration with and without static turbulence promoter were used to characterize and study the biological (antibacterial) activities of LMM peptides. According to the SDS-PAGE results, molecular mass of LMM peptides was smaller than $5 \mathrm{kDa}$. As porous (such as UF) membranes have asymmetric pore size distribution, there is a chance of contamination by untargeted high-molecular-mass peptides $(M>5 \mathrm{kDa})$. Finally, no such contamination was detected in membrane permeate samples.

Furthermore, molecular mass distribution of membrane permeate peptides was determined by LC-ESI-Q-TOF-MS analysis. Fig. 8 represents the distribution profiles of the peptides obtained in filtration with or without static turbulence promoter.

More than $96 \%$ of the peptides (calculated as relative frequency) had molecular mass lower than $1.7 \mathrm{kDa}$ and the highest molecular mass was found to be $3.1 \mathrm{kDa}$ in both types of samples. These results prove that the $5-\mathrm{kDa}$ MMCO UF membrane has a potential to reject the high-molecular-mass peptides $(M>5 \mathrm{kDa})$. The molecular mass distributions of peptides obtained by the two different processes are slightly different, with lower molecular mass of the peptides in the filtrate obtained using static turbulence promoter. However, the difference cannot be considered significant.

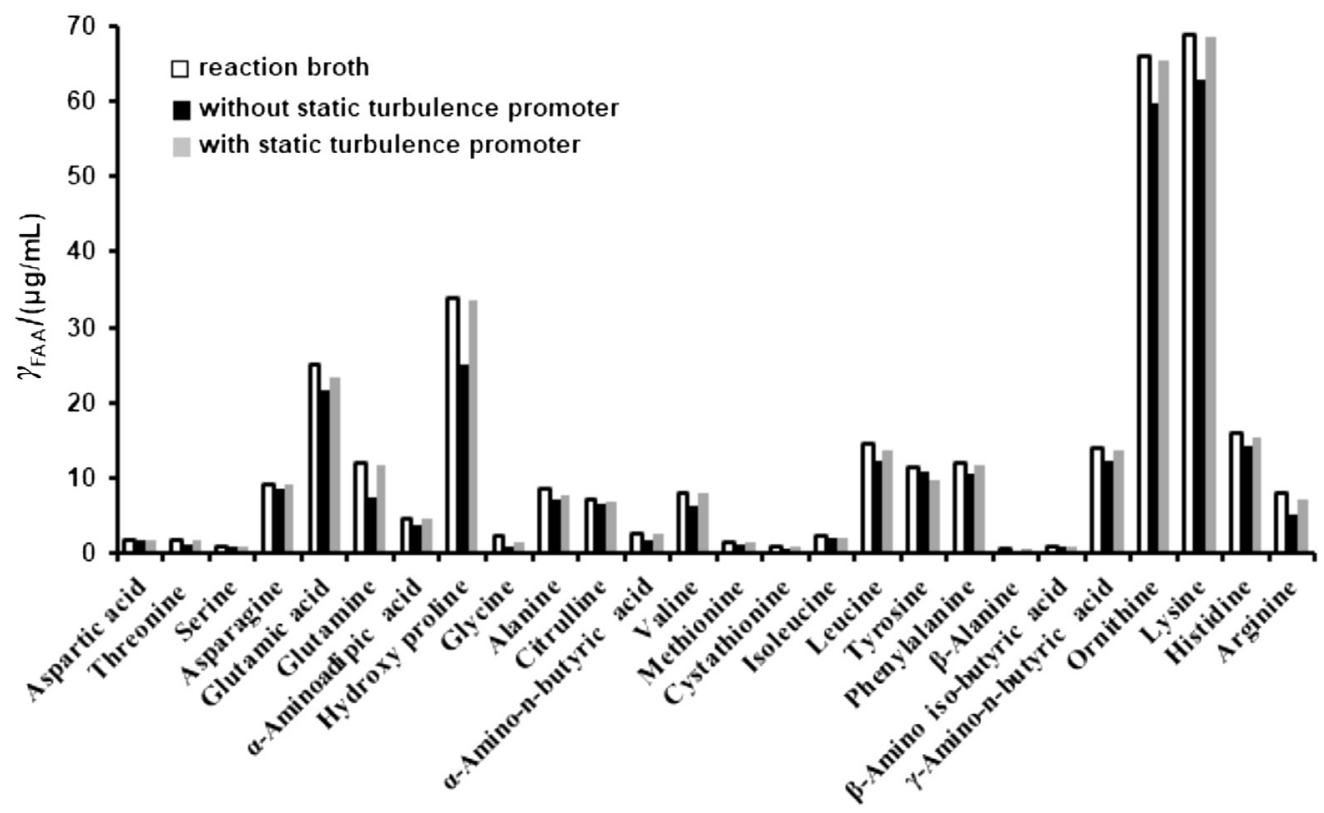

Fig. 7. Mass concentrations of individual free amino acids $\left(\gamma_{\mathrm{FAA}}\right)$ in the reaction broth and ultrafiltration (UF) membrane permeates achieved in the 1st discontinuous diafiltration stage at transmembrane pressure (TMP) of $3 \cdot 10^{5} \mathrm{~Pa}$ 


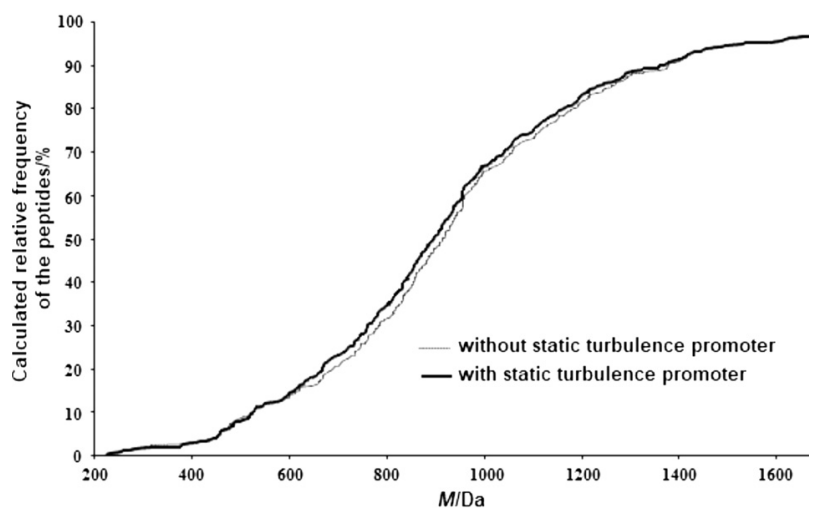

Fig. 8. Molecular mass distributions of the ultrafiltration membrane permeate peptides determined with LC-ESI-Q-TOF-MS setup

Quantification of soy allergens in the prepared LMM peptides

Required sample preparation methods on which extraction efficiency and selectivity of enzyme-linked immunosorbent assay (ELISA) depend were provided by the manufacturer. Therefore, absolute quantification of allergenic proteins is challenging. However, relative quantification eliminates the influence of operationally defined techniques on the determination process. Accordingly, the same ELISA kit was used in the soy allergen quantification of the soybean meal sample and of the soybean meal-derived LMM peptides.

The tryptic hydrolysis of soybean meal and the filtration process resulted in an almost complete removal of detectable soy allergenicity in the permeate containing the LMM peptides. In other words, $>99.9 \%$ of allergenic proteins were either removed by the membrane or hydrolyzed into non-allergenic peptides, calculated on mass basis (i.e. relative reduction based on defatted soybean meal powder). The application of the static turbulence promoter did not affect the final elimination rate of allergenicity. Reduction of allergenicity $>99.9 \%$ could be achieved with and without this device.

\section{Sequencing of LMM peptides}

Peptide sequencing gives another important aspect of the study, especially in the viewpoint of decreased allergenicity. According to the data presented in Table 2, 12 soy proteins were unambiguously identified with at least two residual peptides from the sample, using the static turbulence promoter, and 14 proteins were obtained without this device. Altogether, from the 16 proteins, 10 are considered allergenic, according to UniProt (41) and Gagnon et al. (74). On the other hand, as proteins are rejected by the membrane filtration, any residual allergenicity must come from the tryptic peptides because no allergenic soy protein is described in proteomic databases with $M<5 \mathrm{kDa}$. Soybean meal proteins generally lose allergenicity after proteolytic digestion (75). Therefore, the sequencing information on LMM peptides in the permeate samples contributes to the background knowledge about hypoallergenicity.

In the detected allergenic soy proteins that have disulfide bonds (indicated with letter a in Table 2), no tryp-
Table 2. List of soy proteins that were present in the hydrolyzed samples and samples filtered through a membrane. Proteins were considered to be identified with LC-ESI-Q-TOF-MS/MS peptide sequencing when at least two relevant peptides could be assigned

\begin{tabular}{|c|c|}
\hline $\begin{array}{l}\text { Permeate obtained without a } \\
\text { static turbulence promoter }\end{array}$ & $\begin{array}{l}\text { Permeate obtained with the use } \\
\text { of static turbulence promoter }\end{array}$ \\
\hline \multicolumn{2}{|c|}{ P01070 (trypsin inhibitor A) $)^{a, c}$} \\
\hline \multicolumn{2}{|c|}{ P02858 (glycinin G4) ${ }^{a, c}$} \\
\hline \multicolumn{2}{|c|}{ P04776 (glycinin G1) ${ }^{\mathrm{a}, \mathrm{c}}$} \\
\hline \multicolumn{2}{|c|}{ P08170 (seed linoleate 13S-lipoxygenase-1) } \\
\hline \multicolumn{2}{|c|}{ P09186 (seed linoleate 9S-lipoxygenase-3) } \\
\hline \multicolumn{2}{|c|}{ P09439 (seed linoleate 9S-lipoxygenase-2) } \\
\hline \multicolumn{2}{|c|}{ P13916 ( $\beta$-conglycinin, $\alpha$ chain $)^{\mathrm{b}, c}$} \\
\hline \multicolumn{2}{|c|}{ P13917 (basic 7S globulin) ${ }^{\mathrm{a}, \mathrm{c}}$} \\
\hline \multicolumn{2}{|c|}{ P29531 (P24 oleosin isoform B) } \\
\hline \multicolumn{2}{|c|}{ Q04672 (sucrose-binding protein) } \\
\hline P04405 (glycinin G2) ${ }^{\mathrm{a}, \mathrm{c}}$ & P11828 (glycinin G3) ${ }^{a, c}$ \\
\hline P05046 (lectin) $)^{b, c}$ & P42348 (phosphatidylinositol \\
\hline P11827 ( $\beta$-conglycinin, $\alpha$ chain $)^{\mathrm{b}, \mathrm{c}}$ & 3-kinase, nodule isoform) \\
\hline P25974 ( $\beta$-conglycinin, $\beta$ chain $)^{\mathrm{b}, \mathrm{c}}$ & \\
\hline
\end{tabular}

Proteins with adisulfide bonds, ${ }^{\mathrm{b}}$ glycosylation and callergenic properties according to UniProt (41) and Gagnon et al. (74)

tic peptides could be found neither with the intact disulfide bond nor with free cysteine residues. As neither unfolding agent, e.g. urea, nor reduction or alkylation were applied during tryptic digestion, the peptides with intact disulfide bonds of the proteins identified in the samples (see Table 2) have a theoretical molecular mass over 2.7 $\mathrm{kDa}$, even without taking into account tryptic miscuts. That is, the bare tryptic hydrolysis assisted with the membrane filtration proved to be useful in decreasing the load of allergenic proteins or peptides in the final samples.

Another remarkable difference between the two samples was the lack of most of the glycoprotein-derived peptides (indicated with letter b in Table 2) as only one such allergenic protein was identified in the sample obtained by the filtration with static turbulence promoter, while four were identified in the sample obtained without the use of static turbulence promoter. This result might indicate higher retention of the glycoprotein-derived peptides by the membrane filtration if it is assisted with such an additional device. These characteristics are supported by the ELISA results, showing very low level of soy allergenicity.

\section{Antibacterial activity}

In our study, it was observed that the prepared LMM peptides have antibacterial activity against one of the common food pathogen bacilli, Bacillus cereus. Fig. 9a shows the inhibition zones with diameters of 15 and 10 $\mathrm{mm}$ obtained by UF membrane filtration with and without static turbulence promoter, respectively. It is reported that several plant-based peptides disrupt bacterial cell membranes, as they can create stable pores through which the cellular content leaks out (76). Furthermore, Matsuzaki (77) reported that antibacterial mechanism of plant-based (such as soybean) peptides is detergent-like. The Gram-positive bacteria have negatively charged membrane phospholipids, i.e. teichoic acid and lipoteicho- 
ic acids in their peptidoglycans, which presumably facilitate the electrostatic interactions with positively charged LMM peptides from soybean. Similarly, Wieprecht et al. (78) reported that cationic or amphiphatic hydrophobic peptides interact with the negatively charged bacterial cell membrane, which is the cause of membrane thinning or micellization. Patrzykat and Douglas (79) found that the extent of binding ability of peptides with bacterial cell membrane lipopolysaccharides is neither directly nor inversely proportional to the activity of peptides. The sequence, peptide concentration and chemical composition of the bacterial cell membrane influence the mode of antibacterial action of peptides.

Fig. $9 \mathrm{~b}$ shows the growth curves of Pediococcus acidilactici in membrane permeate with LMM peptides. Interestingly, it was found that the purified LMM peptides could promote the growth of beneficial microbe $P$. acidilactici, which produces $\mathrm{H}_{2} \mathrm{O}_{2}$ during aerobic fermentation, with a fatal effect on its growth. Peptides with hydrophobic amino acid residues in the membrane permeate presumably donate an electron to $\mathrm{H}_{2} \mathrm{O}_{2}$, and as a result, neutralize the reactive oxygen species and promote the growth of $P$. acidilactici. Indeed, Takeuchi (80) reported that special fractions of defatted soybean flour are growth-promoting factors for Pediococcus sp. Herawati and Ishizaki $(81,82)$ also reported that soybean hydrolyzate 'Mieki' enhanced the growth of Pediococcus sp. Furthermore, it is well documented that Soytone (enzymatic hydrolyzate of soybean; Difco, Detroit, MI, USA) enhances the growth of Pediococcus sp. $(83,84)$.

a)
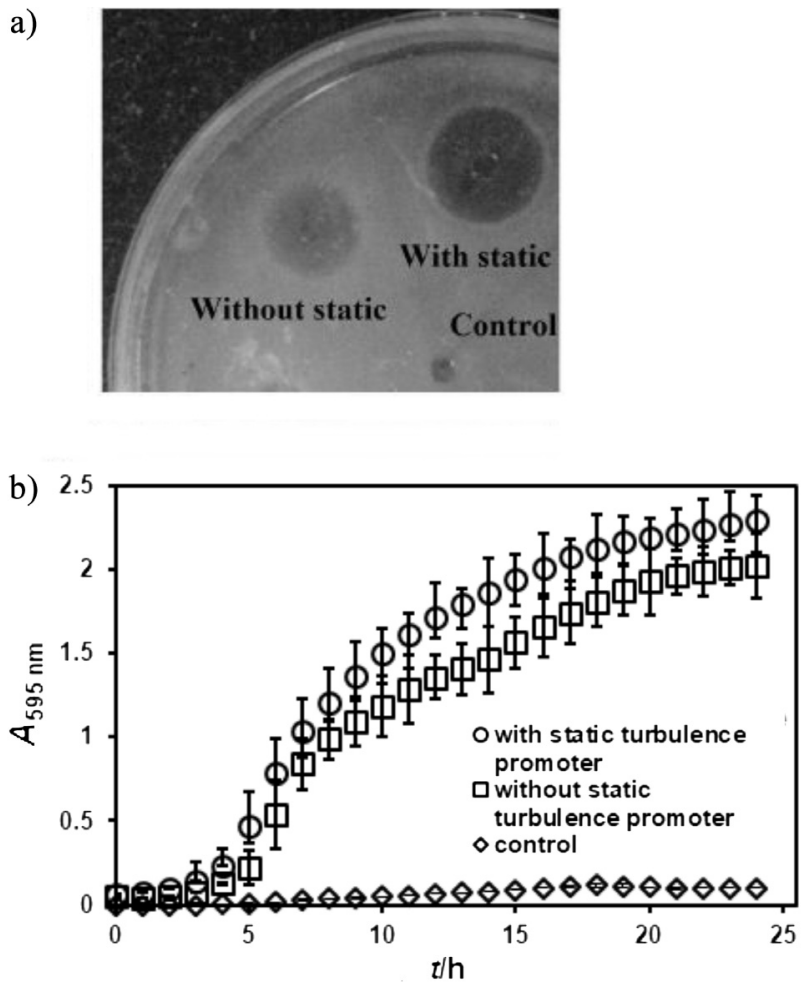

Fig. 9. Zone of inhibition by the low-molecular-mass (LMM) peptides in ultrafiltration membrane permeate against Bacillus cereus (a), and growth of Pediococcus acidilactici HA6111-2 in the presence of LMM peptides from membrane permeate (b)
It is well documented that plant-based LMM peptides have considerable antioxidant capacity and that they can neutralize the effect of $\mathrm{H}_{2} \mathrm{O}_{2}(85)$. The antioxidant capacity of LMM peptides (expressed in ascorbic acid equivalents) obtained with filtration using static turbulence promoter was $60 \mathrm{mg} / \mathrm{L}$, which equals $13.7 \mathrm{mg} / \mathrm{g}$ of LMM peptide from soybean meal. This result is quite high compared with the tryptic digestion of palm kernel cake protein, which has an antioxidant capacity of 11.4 $\mathrm{mg} / \mathrm{g}$ of peptide (86). Even though the antioxidant capacities of different matrices obtained by different analytical methods cannot be directly compared, the antioxidant capacity of the LMM soybean meal peptides could possibly explain why the growth of $P$. acidilactici was promoted, thus highlighting an additional bioactive property of these peptides.

\section{Conclusion}

Valorization of by-products from food and feed industries has grabbed considerable attention. Without any contradiction, production of bioactive peptides from a by-product of vegetable oil processing industry, in this case defatted soybean meal, is one of the promising approaches on the platform of waste valorization. In the present investigation, production of hypoallergenic antimicrobial low-molecular-mass (LMM) peptides from defatted soybean meal was carried out by the combination of enzymatic treatment and membrane filtration based on size exclusion to provide the information for scale-up of the process in food and biochemical process industries. Our approach addresses the production of hypoallergenic antibacterial LMM peptides from defatted soybean meal instead of using soy protein isolate, which is the first such attempt to the best of our knowledge. The proposed method is expected to be a progressive step in the field of recycling and reuse of agricultural waste materials.

\section{Acknowledgements}

First author acknowledges the Hungarian Scholarship Board's Postdoctoral Studies provided by Balassi Institute, Hungary. The study was supported by the TÁMOP 4.2.1./B-09/1/KMR-2010-0005 grant. Authors are grateful to Zrinka Pongrac Habdija, M.A. (Linguistic Editor of Food Technology and Biotechnology) for her kind support to improve the manuscript.

\section{References}

1. McKevith B. Nutritional aspects of oilseeds. Nutrition Bull. 2005;30:13-26.

https://doi.org/10.1111/j.1467-3010.2005.00472.x

2. OECD-FAO Agricultural Outlook. OECD Agriculture statistics (database). 2016. Available from: http://www.agri-outlook.org/commodityanalysis/oilseeds/.

https://doi.org/10.1787/agr-data-en

3. Frikha M, Serrano MP, Valencia DG, Rebollar PG, Fickler J, Mateos GG. Correlation between ileal digestibility of amino acids and chemical composition of soybean meals in broilers at 21 days of age. Anim Feed Sci Technol. 2012;178:103-14. https://doi.org/10.1016/j.anifeedsci.2012.09.002 
4. Yaghoubi M, Mozanzadeh MT, Marammazi JG, Safari O, Gisbert E. Dietary replacement of fish meal by soy products (soybean meal and isolated soy protein) in silvery-black porgy juveniles (Sparidentex hasta). Aquaculture. 2016;464:509.

https://doi.org/10.1016/j.aquaculture.2016.06.002

5. Friedman M, Brandon DL. Nutritional and health benefits of soy proteins. J Agric Food Chem. 2001;49:1069-86. https://doi.org/10.1021/jf0009246

6. Kocher A, Choct M, Porter MD, Broz J. Effects of feed enzymes on nutritive value of soyabean meal fed to broilers. $\mathrm{Br}$ Poultry Sci. 2002;43:54-63. https://doi.org/10.1080/00071660120109890

7. Kidd MT, Morgan GW, JR, Price CJ, Welch PA, Fontana EA. Enzyme supplementation to corn and soybean meal diets for broilers. J Appl Poultry Res. 2001;10:65-70. https://doi.org/10.1093/japr/10.1.65

8. L'Hocine L, Boye JI, Jouve S. Ionic strength and $\mathrm{pH}$-induced changes in the immunoreactivity of purified soybean glycinin and its relation to protein molecular structure. J Agric Food Chem. 2007;55:5819-26. https://doi.org/10.1021/jf070281v

9. Herian AM, Taylor SL, Bush RK. Allergenic reactivity of various soybean products as determined by RAST inhibition. J Food Sci. 1993;58:385-8. https://doi.org/10.1111/j.1365-2621.1993.tb04281.x

10. Collier PD, Cromie DDO, Davis AP. Mechanism of formation of chloropropanols present in protein hydrolysates. J Am Oil Chem Soc. 1991;68:785-90. https://doi.org/10.1007/BF02662173

11. Sun XD. Enzymatic hydrolysis of soy proteins and the hydrolysates utilization. Int J Food Sci Tech. 2011;46:2447-59. https://doi.org/10.1111/j.1365-2621.2011.02785.x

12. Calderón de la Barca AM, Ruiz-Salazar RA, Jara-Marini ME. Enzymatic hydrolysis and synthesis of soy protein to improve its amino acid composition and functional properties. J Food Sci. 2000;65:246-53. https://doi.org/10.1111/j.1365-2621.2000.tb15988.x

13. Panda R, Tetteh AO, Pramod SN, Goodman RE. Enzymatic hydrolysis does not reduce the biological reactivity of soybean proteins for all allergic subjects. J Agric Food Chem. 2015;63:9629-39. https://doi.org/10.1021/acs.jafc.5b02927

14. Zhong F, Zhang X, Ma J, Shoemaker CF. Fractionation and identification of a novel hypocholesterolemic peptide derived from soy protein Alcalase hydrolysates. Food Res Int. 2007;40:756-62. https://doi.org/10.1016/j.foodres.2007.01.005

15. Kong X, Guo M, Hua Y, Cao D, Zhang C. Enzymatic preparation of immunomodulating hydrolysates from soy proteins. Bioresour Technol. 2008;99:8873-79. https://doi.org/10.1016/j.biortech.2008.04.056

16. Xie Y, Liang X, Wei M, Zhao W, He B, Lu Q, et al. Optimization of glutamine peptide production from soybean meal and analysis of molecular weight distribution of hydrolysates. Int J Mol Sci. 2012;13:7483-95. https://doi.org/10.3390/ijms13067483

17. de Oliveira CF, Corrêa APF, Coletto D, Daroit DJ, CladeraOlivera F, Brandelli A. Soy protein hydrolysis with microbial protease to improve antioxidant and functional properties. J Food Sci Technol. 2015;52:2668-78. https://doi.org/10.1007/s13197-014-1317-7

18. Meinlschmidt P, Schweiggert-Weisz U, Brode V, Eisner P. Enzyme assisted degradation of potential soy protein allergens with special emphasis on the technofunctionality and the avoidance of a bitter taste formation. LWT - Food Sci Technol. 2016;68:707-16.

https://doi.org/10.1016/j.lwt.2016.01.023
19. Meinlschmidt P, Sussmann D, Schweiggert-Weisz U, Eisner P. Enzymatic treatment of soy protein isolates: effects on the potential allergenicity, technofunctionality, and sensory properties. Food Sci Nutr. 2016;4:11-23. https://doi.org/10.1002/fsn3.253

20. Chiang WD, Tsou MJ, Tsai ZY, Tsai TC. Angiotensin I-converting enzyme inhibitor derived from soy protein hydrolysate and produced by using membrane reactor. Food Chem. 2006;98:725-32. https://doi.org/10.1016/j.foodchem.2005.06.038

21. Chiang WD, Shih CJ, Chu YH. Functional properties of soy protein hydrolysate produced from a continuous membrane reactor system. Food Chem. 1999;65:189-94. https://doi.org/10.1016/S0308-8146(98)00193-9

22. Beermann C, Euler M, Herzberg J, Stahl B. Anti-oxidative capacity of enzymatically released peptides from soybean protein isolate. Eur Food Res Technol. 2009;229:637-44. https://doi.org/10.1007/s00217-009-1093-1

23. Tsou MJ, Kao FJ, Tseng CK, Chiang WD. Enhancing the antiadipogenic activity of soy protein by limited hydrolysis with Flavourzyme and ultrafiltration. Food Chem. 2010;122:2438. https://doi.org/10.1016/j.foodchem.2010.02.070

24. Tsou MJ, Lin WT, Lu HC, Tsui YL, Chiang WD. The effect of limited hydrolysis with Neutrase and ultrafiltration on the anti-adipogenic activity of soy protein. Process Biochem. 2010; 45:217-22. https://doi.org/10.1016/j.procbio.2009.09.010

25. Tsou MJ, Kao FJ, Lu HC, Kao HC, Chiang WD. Purification and identification of lipolysis-stimulating peptides derived from enzymatic hydrolysis of soy protein. Food Chem. 2013; 138:1454-60. https://doi.org/10.1016/j.foodchem.2012.10.149

26. Giorno L, Mazzei R, Drioli E. Biochemical membrane reactors in industrial processes. In: Drioli E, Giorno L, editors. Membrane operations: Innovative separations and transformations. Weinheim, Germany: Wiley-VCH Verlag $\mathrm{GmbH}$ \& Co. KGaA; 2009. pp. 397-409. https://doi.org/10.1002/9783527626779.ch17

27. ISO 20483:2013. Cereals and pulses - Determination of the nitrogen content and calculation of the crude protein content - Kjeldahl method. Geneva, Switzerland: International Organization for Standardization (ISO); 2013.

28. Lowry OH, Rosebrough NJ, Farr AL, Randall RJ. Protein measurement with the Folin phenol reagent. J Biol Chem. 1951;193:265-75.

29. Margot A, Flaschel E, Renken A. Continuous monitoring of enzymatic whey protein hydrolysis. Correlation of base consumption with soluble nitrogen content. Process Biochem. 1994;29:257-62. https://doi.org/10.1016/0032-9592(94)80066-9

30. Blanch HW, Clark DS. Biochemical engineering. New York, NY, USA: Marcel Dekker Inc.; 1996.

31. Fersht A. Enzyme structure and mechanism. New York, NY, USA: W.H. Freeman; 1985.

32. Braga ARC, Manera AP, da Costa Ores J, Sala L, Maugeri F, Kalil SJ. Kinetics and thermal properties of crude and purified $\beta$-galactosidase with potential for the production of galactooligosaccharides. Food Technol Biotechnol. 2013;51:4552

33. Nath A, Chakraborty S, Bhattacharjee C, Chowdhury R. Studies on the separation of proteins and lactose from casein whey by cross-flow ultrafiltration. Desalin Water Treat. 2015; 54:481-501. https://doi.org/10.1080/19443994.2014.888685

34. Gaspar I, Koris A, Bertalan Z, Vatai G. Comparison of ceramic capillary membrane and ceramic tubular membrane with 
inserted static mixer. Chem Pap-Chem Zvesti. 2011;65:596602. https://doi.org/10.2478/s11696-011-0045-y

35. Anson ML. The estimation of pepsin, trypsin, papain, and cathepsin with hemoglobin. J Gen Physiol. 1938;22:79-89. https://doi.org/10.1085/jgp.22.1.79

36. Laemmli UK. Cleavage of structural proteins during the assembly of the head of bacteriophage T4. Nature. 1970;227: 680-5. https://doi.org/10.1038/227680a0

37. Geer LY, Markey SP, Kowalak JA, Wagner L, Xu M, Maynard $\mathrm{DM}$, et al. Open mass spectrometry search algorithm. J Proteome Res. 2004;3:958-64. https://doi.org/10.1021/pr0499491

38. Craig R, Beavis RC. TANDEM: matching proteins with tandem mass spectra. Bioinformatics. 2004;20:1466-7. https://doi.org/10.1093/bioinformatics/bth092

39. Vaudel M, Barsnes H, Berven FS, Sickmann A, Martens L. SearchGUI: An open-source graphical user interface for simultaneous OMSSA and X!Tandem searches. Proteomics. 2011;11:996-9. https://doi.org/10.1002/pmic.201000595

40. Elias JE, Gygi SP. Target-decoy search strategy for mass spectrometry-based proteomics. Methods Mol Biol. 2010;604:5571 . https://doi.org/10.1007/978-1-60761-444-9_5

41. Apweiler R, Bairoch A, Wu CH, Barker WC, Boeckmann B, Ferro S, et al. UniProt: the universal protein knowledgebase. Nucleic Acids Res. 2004;32:D115-9. https://doi.org/10.1093/nar/gkh131

42. Vaudel M, Burkhart JM, Zahedi RP, Oveland E, Berven FS, Sickmann A, et al. PeptideShaker enables reanalysis of MSderived proteomics data sets. Nat Biotechnol. 2015;33:22-4. https://doi.org/10.1038/nbt.3109

43. Benzie IFF, Strain JJ. The ferric reducing ability of plasma (FRAP) as a measure of antioxidant power: The FRAP assay. Anal Biochem. 1996;239:70-6. https://doi.org/10.1006/abio.1996.0292

44. Karamać M, Amarowicz R, Kostyra H. Effect of temperature and enzyme/substrate ratio on the hydrolysis of pea protein isolates by trypsin. Czech J Food Sci. 2002;20:1-6.

45. Peterson RS, Hill Jr CG, Amundson CH. Effects of temperature on the hydrolysis of lactose by immobilized $\beta$-galactosidase in a capillary bed reactor. Biotechnol Bioeng. 1989;34: 429-37. https://doi.org/10.1002/bit.260340403

46. Busto MD, Owusu Apenten RK, Robinson DS, Wu Z, Casey $R$, Hughes RK. Kinetics of thermal inactivation of pea seed lipoxygenases and the effect of additives on their thermostability. Food Chem. 1999;65:323-9. https://doi.org/10.1016/S0308-8146(98)00216-7

47. Brown ED, Yada RY. A kinetic and equilibrium study of the denaturation of aspartic proteinases from fungi, Endothia parasitica and Mucor miehei. BBA - Protein Struct M. 1991; 1076:406-15.

https://doi.org/10.1016/0167-4838(91)90484-H

48. Owusu RK. A test for the two-stage thermoinactivation model for chymotrypsin. Food Chem. 1993;48:231-5. https://doi.org/10.1016/0308-8146(93)90132-Y

49. Owusu RK, Makhzoum A. Heat inactivation of lipase from Pseudomonas fluorescens P38: activation parameters and enzyme stability at low or ultra-high temperatures. Food Chem. 1992;44:261-8. https://doi.org/10.1016/0308-8146(92)90048-7

50. Naidu GSN, Panda T. Studies on $\mathrm{pH}$ and thermal deactivation of pectolytic enzymes from Aspergillus niger. Biochem
Eng J. 2003;16:57-67.

https://doi.org/10.1016/S1369-703X(03)00022-6

51. Ortega N, de Diego S, Perez-Mateos M, Busto MD. Kinetic properties and thermal behaviour of polygalacturonase used in fruit juice clarification. Food Chem. 2004;88:209-17. https://doi.org/10.1016/j.foodchem.2004.01.035

52. Umeyama H, Hirono S, Nakagawa S. Charge state of His-57Asp-102 couple in a transition state analogue-trypsin complex: a molecular orbital study. Proc Natl Acad Sci USA. 1984;81:6266-70.

https://doi.org/10.1073/pnas.81.20.6266

53. Munch O, Tritsch D. Irreversible thermoinactivation of glucoamylase from Aspergillus niger and thermostabilization by chemical modification of carboxyl groups. BBA - Protein Struct M. 1990;1041:111-6. https://doi.org/10.1016/0167-4838(90)90052-H

54. Shih FF. Deamidation during treatment of soy protein with protease. J Food Sci. 1990;55:127-9. https://doi.org/10.1111/j.1365-2621.1990.tb06033.x

55. Honig DH, Rackis JJ, Wolf WJ. Effects of $\mathrm{pH}$ and salt on yields, trypsin inhibitor content, and mineral levels of soybean protein isolates and wheys. J Agric Food Chem. 1987; 35:967-71. https://doi.org/10.1021/jf00078a026

56. Pacheco WJ, Stark CR, Ferket PR, Brake J. Effects of trypsin inhibitor and particle size of expeller-extracted soybean meal on broiler live performance and weight of gizzard and pancreas. Poultry Sci. 2014;93:2245-52. https://doi.org/10.3382/ps.2014-03986

57. Steiner RF, Frattali V. Purification and properties of soybean protein inhibitors of proteolytic enzymes. J Agric Food Chem. 1969;17:513-8. https://doi.org/10.1021/jf60163a001

58. Smith C, van Megen W, Twaalfhoven L, Hitchcock C. The determination of trypsin inhibitor levels in foodstuffs. J Sci Food Agric. 1980;31:341-50. https://doi.org/10.1002/jsfa.2740310403

59. Porter MC. Concentration polarization with membrane ultrafiltration. Ind Eng Chem Prod Res Dev. 1972;11:234-48. https://doi.org/10.1021/i360043a002

60. Blatt WF, Dravid A, Michaels AS, Nelsen L. Solute polarization and cake formation in membrane ultrafiltration: causes, consequences, and control techniques. In: Flinn JE, editor. Membrane science and technology. Boston, MA, USA: Springer; 1970. pp. 47-97. https://doi.org/10.1007/978-1-4684-1851-4_4

61. Wijmans JG, Nakao S, Smolders CA. Flux limitation in ultrafiltration: osmotic pressure model and gel layer model. J Membrane Sci. 1984;20:115-24. https://doi.org/10.1016/S0376-7388(00)81327-7

62. Wijmans JG, Nakao S, Van Den Berg JWA, Troelstra FR, Smolders CA. Hydrodynamic resistance of concentration polarization boundary layers in ultrafiltration. J Membrane Sci. 1985;22:117-35. https://doi.org/10.1016/S0376-7388(00)80534-7

63. Krstić DM, Tekić MN, Carić MĐ, Milanović SD. The effect of turbulence promoter on cross-flow microfiltration of skim milk. J Membrane Sci. 2002;208:303-14. https://doi.org/10.1016/S0376-7388(02)00308-3

64. Šereš Z, Gyura J, Eszterle M, Djurić M. Separation of nonsucrose compounds from syrup as a part of the sugar-beet production process by ultrafiltration with ceramic membranes. Eur Food Res Technol. 2006;223:829-35. https://doi.org/10.1007/s00217-006-0276-2

65. Ikonić B, Zavargo Z, Šereš Z, Gyura J, Jokić A. Flux improvement during cross-flow microfiltration of wheat starch sus- 
pension using turbulence promoter. Sep Sci Technol. 2012;47: 972-82.

https://doi.org/10.1080/01496395.2011.640379

66. Jokić A, Zavargo Z, Šereš Z, Tekić M. The effect of turbulence promoter on cross-flow microfiltration of yeast suspensions: A response surface methodology approach. J Membrane Sci. 2010;350:269-78. https://doi.org/10.1016/j.memsci.2009.12.037

67. Gaspar I, Tekic P, Koris A, Albert K, Popovic S, Vatai G. CFD and laboratory analysis of axial cross-flow velocity in porous tube packed with differently structured static turbulence promoters. Hem Ind. 2015;69:713-8. https://doi.org/10.2298/HEMIND140312001G

68. Piacentini E, Drioli E, Giorno L. Pulsed back-and-forward cross-flow batch membrane emulsification with high productivity to obtain highly uniform and concentrate emulsions. J Membr Sci. 2014;453:119-25. https://doi.org/10.1016/j.memsci.2013.10.063

69. Xu N, Xing W, Xu N, Shi J. Application of turbulence promoters in ceramic membrane bioreactor used for municipal wastewater reclamation. J Membrane Sci. 2002;210:307-13. https://doi.org/10.1016/S0376-7388(02)00406-4

70. Kuiken KA, Lyman CM. Essential amino acid composition of soy bean meals prepared from twenty strains of soy beans. J Biol Chem. 1949;177:29-36.

71. Riesen WH, Clandinin DR, Elvehjem CA, Cravens WW. Liberation of essential amino acids from raw, properly heated, and overheated soy bean oil meal. J Biol Chem. 1947;167:14350 .

72. Averyhart-Fullard V, Datta K, Marcus A. A hydroxyprolinerich protein in the soybean cell wall. Proc Natl Acad Sci USA. 1988;85:1082-5. https://doi.org/10.1073/pnas.85.4.1082

73. Fischer M, Kofod LV, Schols HA, Piersma SR, Gruppen H, Voragen AGJ. Enzymatic extractability of soybean meal proteins and carbohydrates: heat and humidity effects. J Agric Food Chem. 2001;49:4463-9.

74. Gagnon C, Poysa V, Cober ER, Gleddie S. Soybean allergens affecting North American patients identified by 2D gels and mass spectrometry. Food Anal Methods. 2010;3:363-74. https://doi.org/10.1007/s12161-009-9090-3

75. Wang Z, Li L, Yuan D, Zhao X, Cui S, Hu J, Wang J. Reduction of the allergenic protein in soybean meal by enzymatic hydrolysis. Food Agric Immunol. 2014;25:301-10. https://doi.org/10.1080/09540105.2013.782268

76. Teixeira V, Feio MJ, Bastos M. Role of lipids in the interaction of antimicrobial peptides with membranes. Progr Lipid Res. 2012;51:149-77. https://doi.org/10.1016/j.plipres.2011.12.005

77. Matsuzaki K. Control of cell selectivity of antimicrobial peptides. BBA - Biomembranes. 2009;1788:1687-92. https://doi.org/10.1016/j.bbamem.2008.09.013

78. Wieprecht $\mathrm{T}$, Beyermann $\mathrm{M}$, Seelig J. Binding of antibacterial magainin peptides to electrically neutral membranes: thermodynamics and structure. Biochemistry. 1999;38:10377-87. https://doi.org/10.1021/bi990913+

79. Patrzykat A, Douglas SE. Antimicrobial peptides: cooperative approaches to protection. Protein Pept Lett. 2005;12:1925. https://doi.org/10.2174/0929866053406057

80. Takeuchi T. Growth promotion of Pediococcus halophilus by a basic substance (B-fr.) in soybean miso. J Ferment Technol. 1975;53:1-5.

81. Herawati E, Ishizaki A. Optimization of the culture medium for growth and the kinetics of lactate fermentation by Pediococcus sp. ISK-1. Biosci Biotech Biochem. 1997;61:604-8. https://doi.org/10.1271/bbb.61.604

82. Herawati E, Ishizaki A. Growth stimulation of Pediococcus sp. ISK-1 by Sakekasu (sake filter cake) as a substitute for mevalonic acid. J Fac Agr Kyushu Univ. 1998;43:449-61.

83. Suganthi V, Mohanasrinivasan V. Optimization studies for enhanced bacteriocin production by Pediococcus pentosaceus KC692718 using response surface methodology. J Food Sci Technol. 2015;52:3773-83. https://doi.org/10.1007/s13197-014-1440-5

84. Solberg O, Clausen OG. Classification of certain Pediococci isolated from brewery products. J Inst Brew. 1973;79:227-30. https://doi.org/10.1002/j.2050-0416.1973.tb03528.x

85. Krishnaiah D, Sarbatly R, Nithyanandam R. A review of the antioxidant potential of medicinal plant species. Food Bioprod Process. 2011;89:217-33. https://doi.org/10.1016/j.fbp.2010.04.008

86. Ng KL, Ayob MK, Said M, Osman MA, Ismail A. Optimization of enzymatic hydrolysis of palm kernel cake protein (PKCP) for producing hydrolysates with antiradical capacity. Ind Crops Prod. 2013;43:725-31. https://doi.org/10.1016/j.indcrop.2012.08.017 